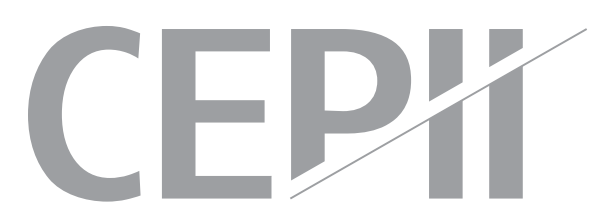

\title{
The Impact of Immigration on Wage Dynamics: Evidence from the Algerian Independence War
}

Anthony Edo

\section{Highlights}

- I investigate the dynamics of wage adjustment to an exogenous increase in labor supply by exploiting the inflow of repatriates to France after the independence of Algeria in 1962.

- I find that the local wages of pre-existing native workers decline in the first years, before returning to their pre-shock level after about 15 years.

- While local wages recovered, this particular supply shock had persistent distributional effects across skill groups. 


\section{Abstract}

This paper investigates the dynamics of wage adjustment to an exogenous increase in labor supply by exploiting the sudden and unexpected inflow of repatriates to France created by the independence of Algeria in 1962. I track the impact of this particular supply shift on the average wage of pre-existing native workers across French regions in 1962, 1968 and 1976. I find that regional wages decline between 1962 and 1968, before returning to their pre-shock level 15 years after. While regional wages recovered, this particular supply shock had persistent distributional effects. By increasing the relative supply of high educated workers, the inflow of repatriates contributed to the reduction of wage inequality between high and low educated native workers over the whole period considered (1962-1976).

\section{Keywords}

Labor Supply Shock, Wages, Immigration, Natural Experiment.

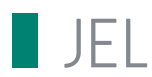

F22, J21, J61.

\section{Working Paper}

\section{CEPI}

CEPII (Centre d'Etudes Prospectives et d'Informations Internationales) is a French institute dedicated to producing independent, policyoriented economic research helpful to understand the international economic environment and challenges in the areas of trade policy, competitiveness, macroeconomics, international finance and growth
CEPII Working Paper

Contributing to research in international economics

C C CEPII, PARIS, 2017

All rights reserved. Opinions expressed in this publication are those of the author(s) alone.

$\begin{array}{ll}\text { Editorial Director: } & \text { CEPII } \\ \text { Sébastien Jean } & \text { 113, rue de Grenelle } \\ & 75007 \text { Paris } \\ \text { Production: } & +33153685500 \\ \text { Laure Boivin } & \text { www.cepii.fr } \\ \text { No ISSN: 1293-2574 } & \text { Press contact: presse@ce }\end{array}$




\title{
The Impact of Immigration on Wage Dynamics: Evidence from the Algerian Independence War ${ }^{1}$
}

\author{
Anthony Edo²
}

\section{Introduction}

The question on how labor markets respond to supply shocks is at the core of the literature on the labor market impact of immigration. However, despite a large body of research on this issue, little is known about the wage dynamics of adjustment to supply shocks (Borjas, 2014; Lewis and Peri, 2015). In fact, existing studies that estimate the impact of migration on wages generally capture medium- or long-run relationships and, therefore, cannot describe their adjustment path towards long-run equilibrium (Wozniak and Murray, 2012; Ruist et al., 2017). This is mainly because these estimates are derived from expected migration episodes. Such episodes indeed allow faster adjustment processes than unexpected ones as they "occur at slower and more predictable rates and are largely driven by economic motivations" (Peri 2016, p. 25).

This paper contributes to the literature on the labor market impact of immigration by investigating the wage dynamics of immigration-induced supply shocks. In order to identify the short- and long-run wage responses to immigration, I exploit the natural experiment created by the end of the Algerian independence war in 1962. This political event generated a sudden and unexpected exodus of around 600,000 repatriates from Algeria to France. This influx increased the pre-existing workforce in France by 1.6 percent on average and up to 7 percent in some southern French regions. I precisely exploit the uneven penetration of repatriates across French regions to investigate their effects on the dynamics of regional and skill-specific wages.

\footnotetext{
${ }^{1}$ I would like to thank George Borjas, Ekrame Boubtane, Frédéric Docquier, Thu Hien Dao, Jennifer Hunt, Nicolas Jacquemet, Sébastien Jean, Joan Monras, Gianmarco Ottaviano, Hillel Rapoport, Jan Stuhler, Farid Toubal, Camilo Umana Dajud, conference audiences and seminar participants at CEMIR workshop on migration, CEPII, PSE migration seminar, University of Lille for very useful comments and suggestions. Any errors which remain are my own.

${ }^{2}$ CEPII, France. E-mail: Anthony.Edo@cepii.fr.
} 
This natural experiment provides a unique opportunity to investigate the wage dynamics of supply shocks not only because the "timing [of the repatriation] was exogenous and the location of the repatriates determined to a large extent by climate (and proximity to port of arrival)" (Friedberg and Hunt, 1995, p. 37), but also because repatriates and nonrepatriates were very close substitutes. In fact, most repatriates from Algeria were French by birth (as opposed to Algerian by birth) and had the same language ability than preexisting natives (McDonald, 1965). This natural experiment thus allows me to investigate the wage consequences of a "standard" labor supply shock, as opposed to other immigration contexts where immigrants and natives are imperfect substitutes due to language ability differences (Peri and Sparber, 2009; Manacorda et al., 2012; Ottaviano and Peri, 2012; Lewis and Peri, 2015).

Hunt (1992) is the first study to exploit this large influx of repatriates from Algeria to France to investigate the labor market consequences of immigration. The study exploits the geographic clustering of repatriates and uses differences across local labor markets to identify their impact on the change in unemployment and wages between 1962 and 1968 in France. She finds that the inflow of repatriates increased the unemployment rate of non-repatriates and decreased the level of French wages. ${ }^{3}$ However, from Hunt (1992, p. 566)'s wage analysis, "it is not possible to distinguish composition effects from effects on the indigenous French". In fact, she uses a wage dataset which does not provide any information to isolate the pre-existing workforce from the repatriates (and other post-1962 waves of migrants). As a result, Hunt (1992)'s estimated wage effects are likely to be contaminated by the changing composition of the wage sample due to the inclusion of repatriates.

The present paper accounts for this identification issue by exploiting new wage data and, most importantly, extends the analysis to explore the dynamics of regional and skillspecific wages generated by the influx of repatriates. I use a rich dataset taken from three wage surveys for the years 1962, 1969 and 1976. It provides enough detailed information to restrict the wage sample to pre-existing native workers. This sample restriction is crucial to estimate a wage response that is not contaminated by composition effects due to the

\footnotetext{
${ }^{3}$ Using variation across region-skill groups, Borjas and Monras (2016); Clemens and Hunt (2017) also find that the supply shock induced by the inflow of repatriates had positive effects on the unemployment rate of pre-existing natives.
} 
large entry of repatriates in France (and other post-1962 waves of migrants).

I estimate the impact of repatriate regional penetration on pre-post wage changes for pre-existing groups of native workers between 1962-1968, 1968-1976 and 1962-1976. This cross-area analysis has the advantage of identifying the total effect of immigration on native wages (Ottaviano and Peri, 2012; Dustmann et al., 2016a). In fact, this approach not only captures the effect of a particular supply shift on the wages of competing workers, but also the cross-effects on the wages of workers with different skills as well as the role of capital accumulation. However, a cross-area analysis could lead to misleading interpretations if repatriates chose their region of residence based on economic considerations, or if pre-existing workers responded by emigrating to other local labor markets (Borjas et al., 1997; Dustmann et al., 2005; Lewis and Peri, 2015).

In order to address the endogeneity of immigration to local economic conditions, I implement an instrumental variable strategy. I follow the literature on migration and use three distinct instruments: local climatic conditions (Hunt, 1992), distance from the sending country (Peri and Sparber, 2009; Dustmann et al., 2016b) and past immigrant spatial distribution (Altonji and Card, 1991; Card, 2001). I moreover show that pre-existing natives did not respond to the regional penetration of repatriates between 1962 and 1968 . This result is consistent with Hunt (1992) who shows that the repatriates did not affect migration across French departments (which are smaller geographical units than regions). As a result, the estimated wage effects between 1962 and 1968 are not contaminated by the reallocation of native workers across local labor markets.

Over the whole period 1962-1976, I find that the influx of repatriates did not affect the regional wage of pre-existing native workers. This finding is robust to alternative estimation techniques, samples and measures of the repatriate supply shock. The insensitivity of regional wages to the inflow of repatriates, however, masks two opposite effects: a negative impact on wages between 1962-1968 and a positive one between 1968-1976. These wage effects are consistent with standard economic theory which predicts a wage response to immigration that is negative in the short-run, positive in the medium-run and potentially null in the long-run after all adjustments have taken place (Ottaviano and Peri, 2008; Borjas, 2013).

The estimated wage effects between 1962-1968 imply an elasticity of wages with re- 
spect to the number of workers ranging from -0.9 to -1.4 and -1.2 to -2.2 after instrumenting. ${ }^{4}$ These estimates are stronger than the baseline estimate in Hunt (1992, p. 567, Table 4) who finds a short-run wage elasticity of -0.8 without instrumenting. This discrepancy in our estimated wage effects is consistent with a potential bias in Hunt (1992)'s wage analysis due to the inclusion of repatriates in the wage sample. ${ }^{5}$ In order to evaluate the bias introduced by this inclusion, I re-estimate the impact of repatriates on wage changes between 1962-1968 without excluding from the sample the large entry of repatriates (and other post-1962 waves of migrants). I find a wage elasticity that is exactly the same as the one found by Hunt (1992). This finding reconciles our results and shows that it is crucial to focus on pre-existing groups of workers to minimize any bias due to composition effects.

I also find that the positive wage change for pre-existing native workers between 1968 and 1976 in response to the influx of repatriates offsets the negative short-run wage effects. This indicates that regional wages fully recovered 15 years after the inflow of repatriates. This rate of adjustment is consistent with Ruist et al. (2017) and Borjas (2016) who respectively find that region- and skill-specific wages recover from positive supply shocks after a decade or more. It is also in line with the literature on the dynamics of demand shocks which finds that U.S. state-level wages tend to return to their pre-shock level after 14 to 20 years (Blanchard et al., 1992; Greenaway-McGrevy and Hood, 2011).

While the influx of repatriates had no significant impact on the change in regional wages between 1962 and 1976, my findings point to persistent distributional effects across skill groups. First, I find that the influx of repatriates decreased the relative wage of high to low educated native workers at the regional level over the whole period considered (1962-1976). This asymmetric impact lies in the fact that the influx of repatriates disproportionately increased the supply of high educated workers, implying a decrease in

\footnotetext{
${ }^{4}$ The more negative effect associated with the IV estimations is consistent with the hypothesis that OLS estimations are positively biased by endogenous immigration inflows. Moreover, this range of elasticities is derived from the sample of men since the estimates for the sample of women is very likely to be contaminated by the increase in the labor market participation of pre-existing women (see Section 8).

${ }^{5}$ More specifically, ignoring the shift in the sample composition due to the inclusion of post-1962 waves of migrants leads to underestimate the true short-run wage impact induced by the influx of repatriates. This upward bias is consistent with the fact that the repatriates probably had higher wages on average as they were relatively more educated than the pre-existing native workers. See also Borjas (2016); Clemens and Hunt (2017); Peri and Yasenov (2015) for a discussion on how changes in the sample composition can affect the measured wage effects induced by immigration.
} 
wage inequality between high and low educated workers. ${ }^{6}$ Second, I use variation across region-skill groups and find a detrimental impact of repatriates on the wages of similarly skilled native workers. This negative impact indicates that the skill groups which received the largest inflow of repatriates experienced the smallest increase in wages (or the largest decrease). These results are consistent with standard economic theory which predicts that immigration should affect the wage structure permanently if the skill composition of immigrants differs from that of natives.

The supply shock induced by the inflow of repatriates also had short-run employment consequences. Between 1962 and 1968, I find detrimental employment effects for preexisting native workers at the regional level. ${ }^{7}$ This result is consistent with Hunt (1992); Borjas and Monras (2016); Clemens and Hunt (2017) who find that the influx of repatriates increased the unemployment rate of non-repatriates at the department level or regioneducation level. I contribute to these studies by decomposing the employment effects induced by the repatriates by gender and across skill groups. First, I show that the adverse employment effects for women is stronger than for men. This asymmetric impact by gender is consistent with the fact that female labor supply is more responsive to changes in wage than male labor supply (Blau and Kahn, 2007; Evers et al., 2008). Second, I show that the influx of repatriates mostly decreased the employment of native workers with a low education level. This skill-specific displacement effect is also larger for women.

The remainder of this paper proceeds as follows. The next section provides a theoretical discussion on the impact of immigration on labor markets. Section 3 gives some background on the inflow of repatriates into France at the end of the Algerian war. Section 4 describes the data and presents some descriptive statistics on the skill differences between pre-existing natives and repatriates. Section 5 shows the main identification strategy and discusses all potential identification issues. While Section 6 investigates the average wage effect induced by the inflow of repatriates, Sections 7 and 8 investigate the distributional consequences across skill groups. I finally extend the analysis to employment outcomes in Section 9. Section 10 concludes.

\footnotetext{
${ }^{6}$ This result echoes the studies by Aydemir and Borjas (2007); Docquier et al. (2014); Edo and Toubal (2015) which respectively show that high-skilled immigration has narrowed wage inequality in Canada, OECD countries and France over the past decades.

${ }^{7}$ The 1975 French census does not allow me to disentangle the pre-existing workers from the repatriates. It is therefore impossible to study the long-run employment effects induced by the repatriates.
} 


\section{Conceptual Framework}

This section provides a simple model that builds on Borjas (2003, 2014); Ottaviano and Peri (2012); Dustmann et al. (2016b) to motivate the empirical specifications and help interpreting the estimated parameters.

\subsection{Theoretical Impact of Immigration}

\subsubsection{Production Function and the Wage Impact of Labor Supply Shocks}

Consider a pre-shock period where an aggregate output $Y$ is produced in a local economy by combining physical capital $K$ and labor $L:^{8}$

$$
Y=A \cdot L^{1-\alpha} \cdot K^{\alpha}
$$

where $A$ is exogenous total factor productivity (TFP) and $\alpha \in(0,1)$ is the capital income share. The labor input can be defined as a composite of different categories of workers who have different skills by using a nested CES structure (Borjas, 2003; Ottaviano and Peri, 2012). Let the labor input $L$ be divided into different skill groups $i$.

$$
L=\left[\sum_{i} \theta_{i} \cdot L_{i}^{\rho}\right]^{1 / \rho} .
$$

The parameters $\theta_{i}$ measure the relative efficiency of each category, with $\sum_{i} \theta_{i}=1$. $\rho=(\sigma-1) / \sigma$ with $\sigma$ being the degree of substitution between skill groups. In equilibrium, profit-maximizing firms pay each skill group a real wage equal to the group's marginal product. We can thus express the impact of an immigration-induced increase in labor

\footnotetext{
${ }^{8}$ I follow the literature on the wage impact of immigration and assume an aggregate production function that is linear homogeneous (See, e.g., Ottaviano and Peri (2012); Brücker et al. (2014); Borjas et al. (2012); Edo and Toubal (2017); Dustmann et al. (2016a)). Also used in the macro-growth literature (e.g. Jones, 2005), this functional form is supported by the fact that capital and labor income shares tend to be constant over time and similar across countries (Gollin, 2002).
} 
supply on the average wage of group $i$ as follows:

$$
d \log w_{i}=d \log w+(1-\rho) \cdot\left(d \log L-d \log L_{i}\right) .
$$

By assuming the following inverse function $r=K^{\lambda}$, where $r$ is the return to capital and $\lambda$ is the inverse elasticity of capital supply, we can show that $d$ logw $=-\alpha \lambda /(1-\alpha+\lambda)$. $d \log L .{ }^{9}$ By substituting this latter expression into Equation 3, one can rewrite the wage changes to the immigration-increase in labor supply as follows:

$$
d \log w_{i}=-\frac{\alpha \lambda}{1-\alpha+\lambda} \cdot d \log L+(1-\rho) \cdot\left(d \log L-d \log L_{i}\right) .
$$

The right-hand side of Equation 4 shows how a labor supply shock can affect the marginal productivity of pre-existing groups of workers. On the one hand, the term $\delta=$ $-\frac{\alpha \lambda}{1-\alpha+\lambda} \cdot d \log L$ captures the effect of a change in the aggregate labor supply on skillspecific wages. The parameter $\delta$ naturally depends on the elasticity of capital supply. In the short-run, when the capital stock is fixed (i.e. the capital supply is inelastic), Equation 4 implies that immigration decreases the wage of workers in all skill groups. Immigration thus lowers the average wage in the economy. In the long-run, however, the capital supply is assumed to be perfectly elastic $(\lambda=0)$. The increase in the capital stock thus offsets the initial adverse impact on average wage.

On the other hand, the last term of Equation 4 shows that immigration generates distributional consequences if the skill composition of immigrants differs from that of natives. In particular, the skill groups that experience the largest supply shocks would be the ones where wages decrease the most or increase the least (Ottaviano and Peri, 2008; Borjas, 2013). Equation 4 moreover indicates that even in the long-run, after all adjustments have taken place, the distributional consequences of immigration remain (Aydemir and Borjas, 2007; Ottaviano and Peri, 2012). ${ }^{10}$

\footnotetext{
${ }^{9}$ From Equation 1, one can show that $d \log w=\alpha \cdot[d \log K-d \log L]$ and $d \log r=(\alpha-1) \cdot[d \log K-d \log L]$. Then, one can substitute $d \log K$ in the wage equation by its expression derived by equating $d \log r=\lambda \cdot d \log K$ and $d \log r=(\alpha-1) \cdot[d \log K-d \log L]$.

${ }^{10}$ The theoretical prediction that immigration has persistent distributional consequences hinges on the assumption that physical capital has the same degree of substitutability with all skill groups. An alternative
} 


\subsubsection{Measure of the Labor Supply Shock}

In order to estimate the average impact of an immigration-induced increase in labor supply on wages, I measure immigrant penetration at the regional level rather than skill-level. Similar to Altonji and Card (1991); Goldin (1994); Smith (2012); Dustmann et al. (2013, $2016 b)$, this strategy has the main advantage to capture the total effect of immigration on wages (Dustmann et al., 2016a). In fact, in addition to capturing the "own" effect of immigration on the wage of workers in a particular skill group, this approach accounts for the complementarity effects across skill groups and across capital and labor. ${ }^{11}$

In order to define regional supply shocks, I first consider a pre-shock period $(t=0)$. A change in the labor supply induced by immigration in the skill group $i$ can thus be written as follows:

$$
d \log L_{i}=\log \left(\frac{N_{i}^{1} \cdot\left(1+m_{i}\right)}{N_{i}^{0}}\right)
$$

where $m_{i}=M_{i} / N_{i}^{1}$ is the relative number of immigrants in the post-shock period $t=1$. By assuming an inelastic native labor supply, one can show that $d \log L_{i} \simeq m_{i}$, which is the immigration-induced percent supply shift for skill group $i$ (Borjas, 2003; Borjas and Monras, 2016). ${ }^{12}$ I then follow Dustmann et al. (2016b) and express skill-group specific supply shocks $d \log L_{i}$ as a function of the aggregate supply shock $\bar{m}=M / N^{1}$ as follows:

$$
d \log L_{i}=\frac{s_{i}^{M}}{s_{i}^{N}} \cdot \frac{M}{N^{1}}=\pi_{i} \cdot \bar{m},
$$

to this assumption is studied by Lewis $(2011,2013)$ who allow for capital-skill complementarity (i.e. capital and high skilled labor are complements and capital and low skilled labor are substitutes). Capital-skill complementarity implies that the short-run wage response to immigration disappears in the long-run - i.e., relative wages across skill groups are not affected by skill mix changes. See Borjas (2014, Chapter 6) and Lewis and Peri (2015) for further complements on how capital-skill complementarity can affect the wage impact of immigration.

${ }^{11}$ In Section 8, I measure labor supply shocks at the region-skill level in order to estimate the "own" effect of immigration on the wage of natives with similar skills.

${ }^{12}$ See Borjas and Monras (2016); Dustmann et al. (2016b) who explore the theoretical impact of immigration on wages when assuming a labor supply that is elastic. 
where $s_{i}^{M}$ and $s_{i}^{N}$ are respectively the share of workers within the skill group $i$ (in head counts) among immigrants and natives (i.e., $s_{i}^{M}=M_{i} / M$ and $s_{i}^{N}=N_{i}^{1} / N^{1}$ ). The parameter $\pi_{i}$ thus measures the difference in the skill distribution between immigrants and natives. By using the properties of the CES production function and Equation 6, one can show that:

$$
d \log L=\sum_{i} \frac{s_{i}}{s_{L}} \cdot d \log L_{i}=\pi \cdot \bar{m}
$$

where $\pi=\sum_{i} \frac{s_{i}}{s_{L}} \cdot \pi_{i}$ is the weighted average of the relative density of immigrants across skill groups. Based on Equation 4, the skill-specific wage impact of an immigrationinduced increase in labor supply can be written as:

$$
d \log w_{i}=\left[(\delta+1-\rho) \cdot \pi+(\rho-1) \cdot \pi_{i}\right] \cdot \bar{m} .
$$

In order to investigate the impact of the aggregate supply shock $\bar{m}$ on the average wage of group $i=1$ relative to group $i=2$, one has to consider the following relative wage equation:

$$
d \log w_{1}-d \log w_{2}=(\rho-1) \cdot\left(\pi_{1}-\pi_{2}\right) \cdot \bar{m},
$$

where $\rho-1=-1 / \sigma$. The distributional effect of $\bar{m}$ across skill groups depends on the elasticity of substitution $\sigma$ between the two groups and is proportional to the relative supply shift. If the immigrant contribution to the supply of skills is mostly concentrated within group $1, \pi_{1}>\pi_{2}$, the impact of immigration on the relative wage of group 1 should be negative. This negative impact is stronger when the degree of substitution between groups is small. Moreover, Equation 9 shows that the relative wage effects induced by immigration across skill groups should be persistent and invariant over time. 


\subsection{Labor Market Adjustments to Supply Shocks and Wage Dynam- ics}

For each local labor market, Equation 4 predicts that the average wage of pre-existing workers should first decline in response to positive labor supply shocks. In the long-run, however, the average wage should recover through capital accumulation in each market. ${ }^{13}$ As shown by Lewis (2011); Dustmann and Glitz (2015), the recovery of local wages could also be due to the adoption of new technologies. By affecting the relative supply of inputs, Lewis (2011)'s model predicts that the economy should use more intensively the input that have become relatively more abundant through changes in production techniques, leading to the recovery of input prices. ${ }^{14},{ }^{15}$

The recovery of local wages may not only be due to within-local adjustments. In fact, the reallocation of labor and capital across localities should also contribute to mitigate the initial adverse effect of labor supply shocks on local wages (Borjas et al., 1997; Card, 2001; Dustmann et al., 2005; Lewis and Peri, 2015). Borjas (2006); Boustan et al. (2010); Monras (2015a); Braun and Weber (2016); Dustmann et al. (2016b), for instance, show that workers tend to respond to local labor supply shocks by relocating into low-immigration areas. ${ }^{16}$ These internal flows across local labor markets spread the economic impact of immigration to other labor markets and dissipate the shock through the national economy. ${ }^{17}$

\footnotetext{
${ }^{13}$ In Equation 1, the linear homogeneity of the production function implies that the capital stock should increase by the same proportion as the workforce. The average wage should thus return to its pre-shock equilibrium.

${ }^{14}$ To support this prediction, Lewis (2011) shows that, over the 1988-1993 period, mechanization and automation was faster in US metropolitan areas with the lowest penetration of less educated immigrants i.e., low-skill immigration increased the use of more labor-intensive technologies. In accordance with Lewis (2011)'s model, Dustmann and Glitz (2015) show for Germany that local labor supply shocks are mostly absorbed through within-firm adjustments in production techniques.

${ }^{15}$ The model by Lewis (2011) differs from international trade models which suggest that immigration can be absorbed by the economy through changes in the production mix without any changes in input prices. In this regard, the study by Rybczynski (1955) implies that an influx of labor could simply change the output mix through increasing the labor-intensive production and decreasing the capital-intensive production.

${ }^{16}$ There is, however, no consensus on how the inflow of immigrants in a local labor market affects native internal migration (Borjas et al., 1997; Card, 2001; Peri and Sparber, 2011a; Foged and Peri, 2016).

${ }^{17}$ Natives may also respond to an immigration-induced increase in labor supply by moving towards other occupations (Peri and Sparber 2009, 2011b; Cattaneo et al. 2013; Foged and Peri 2016) and acquiring more education (Hunt, 2016).
} 
By affecting the level of wages, a local labor supply shock should trigger various adjustments within and across localities contributing to the recovery of local average wages. Economic theory, however, does not offer any guidance on how long it takes for the average wage to recover from labor supply shocks. Although the studies by Cohen-Goldner and Paserman (2011); Borjas (2016) investigate the adjustment of skill-specific wages (rather than average wage) in response to immigration, they are informative on the dynamics of wage adjustments. By exploiting the massive flows of Russian Jews into Israel in the early 1990s, Cohen-Goldner and Paserman (2011) find that occupational-level wages decline in the first year, before returning to their pre-immigration level after 7 years. Borjas (2016) investigates the wage impact of the Mariel Boatlift and shows that the relative wage of low-skill workers in Miami recovered after a decade. ${ }^{18}$ Moreover, Ruist et al. (2017) exploit non-experimental U.S. data to investigate the wage impact of immigration and find that local-level wages had not returned to their pre-shock level after a decade.

The literature on the dynamic response of wages to demand shocks points to a longer adjustment process. In their influential study, Blanchard et al. (1992) show that a demand shock which reduces the level of employment by 1 percent in a particular U.S. state causes an immediate detrimental wage response. After 6 years, manufacturing wages start the recovery and return to their pre-shock level after 20 years. By using the same methodology, Greenaway-McGrevy and Hood (2011) focus on common negative demand shocks rather than state-specific shocks and find that wages do not reach their long-run level until 14 to 18 years after the shock. The studies by Amior and Manning (2015); Monras (2015b) also indicate that spatial adjustments to local demand shocks take a decade or more.

\section{Independence of Algeria and the Repatriation to France}

The end of the Algerian conflict and the subsequent independence triggered massive flows of people moving from Algeria to France. Mass migration to France started after

\footnotetext{
${ }^{18}$ By exploiting the large inflow of Mexican immigrants to the U.S. in 1995, Monras (2015a) also finds that the negative wage response to this supply shock for low skilled native workers at the State level tended to lessen during the four subsequent years (from 1996 to 1999). See also the contributions by Braun and Weber (2016); Colas (2016) who respectively analyze the dynamic effects of local labor supply shocks on the German and U.S. labor markets by using a dynamic model of regional labor markets.
} 
the signature of the Accords of Evian - a ceasefire agreement - on March 18, 1962 and mostly took place after the referendum held in France approving them on 8 April 1962. On 3 July 1962, France officially recognized the independence of Algeria after an eight-year war.

According to the French census implemented in March 1968, one million of people moved to France over the 1962-1968 period. This large influx mostly occurred between April and December 1962 (McDonald, 1965; Zytnicki, 1998; Moumen, 2010), with a peak during the summer where 500,000 repatriates arrived in France (Baillet, 1975).

Figure 1 presents the flows of people moving from Algeria to France between 1962 and 1968. Over the 992,900 repatriates who came to France between 1962 and 1968, 60 percent (i.e., 576,888 repatriates) arrived in France between March and December 1962. This peak was then followed by a continuous decline in the inflow of repatriates from Algeria. Figure 1 clearly illustrates that the end of the Algerian conflict led to a substantial and rapid influx of repatriates to France in 1962. The exogenous timing of this massive influx leads Hunt (1992); Borjas and Monras (2016) to exploit this natural experiment in order to investigate the labor market effects of immigration. ${ }^{19}$

Figure 1 also presents the composition of inflows by nationality at birth. Most repatriates who emigrated to France over the period were French by birth and, therefore, had a French origin. From March to December 1962, 91.1 percent of the repatriates were French by birth, among which 20.2 percent were born in metropolitan France. The remaining 8.9 percent were Algerian by birth, or born with another nationality. The over-representation of French-born repatriates implies that the exodus from Algeria differs from other migration contexts where immigrants and natives are imperfect substitutes due to language ability differences (Peri and Sparber, 2009; Peri, 2016). By following the same education system and passing identical exams, repatriates and natives do not differ in terms of their language ability and other cultural traits (McDonald, 1965). Moreover, the repatriates should not have any particular issues with the transferability of their learning. As a result, natives and repatriates with similar observable skills (e.g., education, occupation and age) should be very close substitutes. The repatriation to France therefore offers a unique opportunity to better understand how labor markets respond to supply shocks.

\footnotetext{
${ }^{19}$ See also the contribution by Clemens and Hunt (2017) who revisit the impact of the inflow of repatriates on native employment opportunities between 1962 and 1968.
} 


\section{Data and Descriptive Statistics}

This section presents the data used to estimate the effects of repatriates from Algeria on wages, employment and internal migration of pre-existing native workers. After describing the data and selected sample, I provide some descriptive statistics about repatriates and natives.

\subsection{Data}

This paper uses five individual datasets collected by the French national institute (INSEE): the censuses from 1962 and 1968 as well as three wage surveys published in 1964, 1970 and 1977 ("Enquête Formation et Qualification Professionnelles" or FQP). These datasets provide detailed, comparable and coherent information on demographic, economic and social characteristics at the individual level. I use the 1968 French census to measure the repatriate-induced increase in labor supply. The FQP allows me to examine the dynamics of the impact of repatriates on the wages of pre-existing groups of workers.

\subsubsection{Census Data}

I use the 1962 and 1968 census extracts. They respectively cover a random sample of 5 percent and 25 percent of the French Population. The very large 1968 census extract allows me to infer with precision the number of repatriates who came to France after the Algerian war of independence.

I restrict my attention to the repatriates who arrived in France between March and December 1962. ${ }^{20}$ The census indeed distinguishes two sub-periods for the year 1962: January to February and March to December. As the outflow of people following the Algerian independence starts mostly in April and further intensified in the summer of 1962, I exclude the individuals who immigrate to France in January and February. I also exclude the repatriates from Algeria who arrived in France between 1963 and 1968 as their migration could have been driven by economic concerns. ${ }^{21}$

\footnotetext{
${ }^{20}$ I use the department of residence on first January 1962 (e.g., a French department or Algeria) and the year of immigration to France to infer the number of repatriates.

${ }^{21}$ In their studies on the labor market impact of the repatriation into France, Hunt (1992); Borjas and
} 
The 1968 census allows me to compute the size of the native population which prevails before March 1962. Specifically, I use the department of residence on first January 1962 (e.g., a French department or Algeria) to infer the number of pre-existing natives. As in Borjas (2003); Ottaviano and Peri (2012), I define a native as a person born in France or outside France with the French citizenship.

As in Hunt (1992); Borjas and Monras (2016); Clemens and Hunt (2017), I exploit the French censuses of 1962 and 1968 to investigate the impact of repatriates on the employment opportunities of pre-existing native workers. ${ }^{22}$ I also exploit these two censuses to investigate the impact of repatriates on native internal migration across French regions. It is important to notice that the 1962 census was implemented in March, just before the massive arrival of repatriates during the summer (see Section 3). As a result, this census "provides data describing conditions before the arrival of the repatriates" (Hunt, 1992, p. 562).

\subsubsection{Wage Data}

The wage data are taken from three surveys called "Enquête Formation et Qualification Professionnelles" (FQP) and published by the INSEE in 1964, 1970 and 1977. They cover a random and representative sample of workers and respectively have 14,676 observations, 23,305 observations and 39,103 observations with positive salary income. I use these data to estimate how the wages of pre-existing native workers respond to the inflow of repatriates from Algeria.

The FQP reports workers net annual wages, as well as various information on socioeconomic characteristics such as age, nationality at birth, gender, region of residence, education level, sector of activity, year of the first job, etc. In order to study the wage change of pre-existing native workers in response to immigration, I exclude from the sample all workers (i) who arrived in France after 1961 and (ii) who start their professional career after 1961. Because the 1964 FQP has no information on the year of arrival to

Monras (2016); Clemens and Hunt (2017) deal with the repatriates who arrived in France between 1962 and 1968. Hunt (1992) moreover excludes all repatriates whose family name was Arab or Berber and, therefore, restricts her analysis to the repatriates with a European origin.

${ }^{22}$ Notice that it is not possible to extend the employment analysis by using the 1975 French census because it provides no information to distinguish the repatriates from pre-existing populations. 
France, I restrict the wage sample to the natives who lived in 1959 in metropolitan France. As no information on the country of birth is available, I define a native worker as anyone born with the French nationality. This definition is more restrictive than the one generally used in the literature which would also consider the non-French citizens born in France as natives (Borjas, 2003; Ottaviano and Peri, 2012; Edo and Toubal, 2017). Moreover, this definition are very unlikely to affect the empirical results as the population of workers born in France with a foreign nationality is negligible, representing only 1 percent of the total population of workers according to the 1968 census.

The 1964 FQP reports the net annual wages for 1962. I thus use 1962 as the "prearrival" year. ${ }^{23}$ The use of 1962 rather than 1961 wages should bias the estimated impact of the inflow of repatriates on the wage change of natives toward zero if some wage adjustments already occurred in 1962. In the 1964 FQP, wages are reported as a categorical variable. I impute annual wages as follows: 3,500 for less than 4,000 Francs, 4,500 for 4,000-4,999 Francs, 5,500 for 5,000-5,999 Francs, 7,000 for 6,000-7,999 Francs, 9,000 for 8,000-9,999 Francs, 12,500 for 10,000-14,999 Francs, 17,500 for 15,000-19,999 Francs, 27,500 for 20,000-34,999 Francs, 42,500 for 35,000-49,999 Francs, 55,000 for 50,000 Francs and more.

The 1970 and 1977 FQP data report the net annual wages of workers for the years 1969 and 1976, respectively. In these data, the wage variable is continuous. The structure of these surveys allows me to only consider the native workers who were in France before 1962 which is the year of the migration shock. As a result, these wage data allow me to compute the mean log annual wage of pre-existing native workers to measure the price of labor for the years 1962, 1969 and 1976. ${ }^{24}$

Table 1 reports the sample size used to compute the average wage of pre-existing native workers for each region in 1962, 1969 and 1976. After all sample restrictions, I have an average number of 9,408 individual observations per year to compute regionskill specific wages for the sample of men, against 3,565 observations for the sample of women.

\footnotetext{
${ }^{23}$ Whereas Hunt (1992) uses another wage dataset, she also had to use the year 1962 to measure the wage of pre-existing workers.

${ }^{24}$ Since wages are always reported in nominal terms, I deflate the data using the French Consumer Price Index provided by the INSEE.
} 
In the empirical analysis, I divide each local labor market into eight skill groups. I therefore compute mean wages on the basis of an average yearly sample size of 56 observations for men and 21 observations for women. As the empirical estimates may be sensitive to the sample size used to compute average wages, I will use alternative definition of skill groups to increase the sample size per group and have a more precise measure of region-skill specific wages.

\subsubsection{Selected Sample}

I restrict the empirical analysis to individuals aged from 18 to 64 , who are in the labor force (i.e., employed or unemployed) and not enrolled at school. I also exclude the selfemployed (farmers and entrepreneurs) since the income-setting mechanism in these occupations should differ from the wage-setting of all other workers. I systematically use weights computed by the INSEE when aggregating the data. The weight indicates the number of individuals each observation represents in the total population.

As emphasized in Hunt (1992); Borjas and Monras (2016); Clemens and Hunt (2017), the geographical dimension is the main relevant source of variation to study the labor market impact of the influx of repatriates into France. I thus use the 21 French regions to compute local supply shocks. ${ }^{25}$ While Hunt (1992) uses the 88 French departments, I exploit a larger level of aggregation as the wage data only provide information at the regional level. ${ }^{26}$

In order to study the nature of the repatriate-induced supply shift across different skill groups and its effect on the wage structure, I decompose the sample across education groups and occupations. I use four education groups:

- A high education group composed of people who have a college degree, some college or a French diploma giving access to the university (i.e., "Baccalauréat").

- A medium education group composed of people who have a high school degree (such as "CAP" or "BEP") and a French diploma giving access to high school (i.e.,

\footnotetext{
${ }^{25}$ I exclude Corsica from the sample as the wage data do not report any wage information for this region. Hunt (1992) also excludes Corsica from the analysis.

${ }^{26}$ Using large geographic areas has the advantage to limit any bias in the estimated wage impact of immigration arising from the reallocation of the native labor supply to to other localities (Borjas, 2006).
} 
"BEPC").

- A low education group composed of people who have an elementary school diploma (i.e., "CEP”).

- A very low education group composed of people who have no diploma.

Using four education groups is enough rich to analyze the nature of the supply shock induced by the repatriates across education groups and provides enough observation to compute the average wage for each group. ${ }^{27}$ The empirical results are robust to using three and six education groups rather than four. To build six educational categories, I break down the group of high educated individuals into college graduates and college dropouts and the group of medium educated people into high school graduates and high school dropouts. With the two lowest education groups, I thus have six educational categories. The classification with three educational categories merges the groups of primary and pre-primary education.

When estimating the impact of repatriates on the employment and internal migration of pre-existing native workers, I have to use the 1962 census. This census, however, does not report the educational attainment for 54.5 percent of non-students individuals aged 18-64. By analyzing the educational composition of the French population in 1962 and 1968, Monfort (1972) reports that the social importance of having a diploma could have led individuals with no education to not report that information. I thus follow Monfort (1972)'s suggestion and assume that all individuals who do not report their education level have no diploma (i.e., a very low level of education).

The censuses and FQP data also have precise information on the sector of activity of workers (i.e. service, agriculture, construction and industry). Given the fact that the repatriates disproportionately increased the number of workers in service occupations (e.g. administrative, trade and banking activities, transport sector, car mechanic, army and other civil servants occupations), I define two broad occupational groups: service and non-service occupations. The non-service occupations regroups all activities related to agriculture, construction and industry.

\footnotetext{
${ }^{27}$ Borjas and Monras (2016); Clemens and Hunt (2017) also use four education groups to investigate the impact of repatriates on native employment at the education-region level.
} 


\subsection{Descriptive Statistics}

According to the 1968 French census, the repatriates who arrived in France between March and December 1962 represented 1.6 percent of the pre-existing native labor force. The inflow of repatriates increased the workforce by 1.8 percent for the sample of men and 1.3 percent for the sample of women. This supply shift was unevenly distributed within the pre-existing native population: the inflow of repatriates disproportionately increased the supply of high educated workers, in the south of France and within service occupations.

As pointed out by several studies ${ }^{28}$ many repatriates settled in the south of France because of its proximity to Algeria in terms of climatic conditions and geographical distance and because they were composed of many Algerian-born people who settled there during the Algerian war of independence (1954-1962).

Figure 2 shows that male and female repatriates disproportionately increased the workforce in southern regions, such as Provence-Alpes Côte d'Azur, Languedoc-Roussillon, Midi-Pyrénées and Rhône-Alpes. In contrast, northern regions (such as Nord-Pas-deCalais which is the most northern region in France) experienced a small increase in their labor force due to the repatriates. Figure 2 also shows that these local supply shocks were always stronger for the sample of men. In Provence-Alpes Côte d'Azur, e.g., male repatriates increased the male labor force by 6.6 percent, while female repatriates increased the female labor force by 5.1 percent. $^{29}$

Table 2 reports the distributions of pre-existing natives and repatriates across education, age and occupation groups. For each group, I first compute the relative density of repatriates (i.e., $\pi_{i}=\left(M_{i} / M\right) /\left(N_{i}^{1} / N^{1}\right)$ as we have seen in Section 2.1.2 - Equation 6). This measure captures the difference in the skill distribution between repatriates and natives. I also compute the percent supply shift induced by the repatriates (i.e., $m_{i}=M_{i} / N_{i}^{1}$ as we have seen in Section 2.1.2 - Equation 5).

In Table 2, the decomposition across education groups shows that the relative density

\footnotetext{
${ }^{28}$ See, e.g., Hunt (1992); Okkerse (2008); Borjas and Monras (2016) for economic studies and McDonald (1965); Baillet (1975); Zytnicki (1998) for historical studies.

${ }^{29}$ This differential increase in labor supply is partly due to differences in participation rates. In fact, the participation rate of female repatriates is lower than for female natives (respectively 35.4 vs 42.3 percent), whereas the participation rate of male repatriates is higher than for male natives (respectively 92.0 vs 90.1 percent) - see Appendix-Table 9.
} 
of repatriates is the strongest within the high educated group - i.e., the inflow of repatriates disproportionately increased the supply of high educated workers. ${ }^{30}$ As a result, the male native workforce with a high level of education increased by 2.3 percent, against 1.7 percent in the lowest educational categories. For the sample of women, the influx of repatriates increased the relative supply of high and medium educated native workers by more than 1.5 percent, against 1.0 percent for the two lowest educational categories. ${ }^{31}, 32$

Table 2 also indicates that the repatriates are over-represented in the cohort aged 30-44 and in service occupations (such as professor and scientific profession, teachers, health professions and administrative employees). ${ }^{33}$ More specifically, the inflow of repatriates increased the relative number of workers in service occupations by 2.6 percent for men and 1.5 percent for women. It increased the number of workers in non-service occupations by 1.1 percent for men and 0.4 percent for women.

\section{Empirical Strategy}

\subsection{Econometric Equation}

In order to estimate the impact of a sudden and massive inflow of migrants on the labor market outcomes of natives, a common approach is to implement a difference-indifferences strategy by comparing wage (or employment) changes in the regions affected by the immigrant inflow to wage (or employment) changes in unaffected regions with similar characteristics (Card, 1990; Borjas, 2016; Peri and Yasenov, 2015; Foged and Peri, 2016; Tumen, 2016). Instead of using a post-treatment dummy, some studies rather use a measure of immigrant penetration across geographical areas to define a variable with different "treatment intensity" (Altonji and Card, 1991; Hunt, 1992; Dustmann et al.,

\footnotetext{
${ }^{30}$ The fact that the repatriates were more skilled than the pre-existing labor force is also documented in Baillet (1975); Borjas and Monras (2016); Clemens and Hunt (2017).

${ }^{31}$ Conditional on education, the percent supply shifts induced by the repatriates are always weaker for women. This is partly explained by the lower participation rate of female repatriates relative to male repatriates (Appendix-Table 9).

${ }^{32}$ As shown in Appendix-Table 10, the increase in the relative supply of high educated workers took place for most regions.

${ }^{33}$ These facts are also documented by French studies, e.g. Baillet (1975); Zytnicki (1998).
} 
2016b; Borjas and Monras, 2016; Clemens and Hunt, 2017). ${ }^{34} \mathrm{I}$ also use a differencein-differences setting with variable treatment intensity and estimate the following baseline equation:

$$
\triangle \log _{i j r}=\alpha+\beta \cdot \Delta m_{r}+\delta_{i j}+\triangle \epsilon_{i j r},
$$

where,

- $\triangle \log w_{i j r}=\log w_{i j r}^{1}-\log w_{i j r}^{0}$ is the change in the wage of pre-existing native workers between two points in time in region $r$, education $i$ and occupation $j(t=0$ for the pre-migration period and $t=1$ for the post-migration period).

- $\Delta m_{r}=$ Repatriates $_{r} /$ Natives $_{r}^{1968}$ is the change in the pre-existing native labor supply due to the inflow of repatriates from Algeria in region $r$.

- $\delta_{i j}$ is a vector of skill fixed effects to control for all skill group-specific change in wages.

- $\triangle \epsilon_{i j r}$ is the error term which captures all the determinants of native wage changes in region-skill groups other than the response to the inflow of repatriates.

Differencing has the advantage to eliminate all time-invariant regional characteristics that may affect the level of wages and the spatial distribution of repatriates. The parameter $\beta$ identifies the effect of the inflow of repatriates across regions on the change in the wage of pre-existing native workers in a particular region-skill group before $(t=0)$ and after $(t=1)$ the supply shift. More specifically, it gives the percentage change in the wage of a particular skill group in response to a percentage point change in the size of the native labor force due to the inflow of repatriates.

In Equation 10, I do not assign repatriates to a particular skill group - i.e., $\Delta m_{r}$ is not specific to skill groups. The parameter $\beta$ thus identifies the total wage effect due to

\footnotetext{
${ }^{34}$ Friedberg (2001) also uses a difference-in-differences estimation to investigate the labor market impact of the massive immigrant flows of Russian Jews into Israel in the early 1990s at the occupational level. See also the contributions by Goldin (1994); Peri (2012); Smith (2012); Monras (2015a); Foged and Peri (2016) who use first-difference estimations to identify the labor market impact of immigration.
} 
an immigration-induced increase in labor supply as derived in Equation 4. This estimation strategy is similar to Altonji and Card (1991); Goldin (1994); Smith (2012); Dustmann et al. (2013); Monras (2015a); Dustmann et al. (2016b); Ortega and Verdugo (2017) and has several advantages. First, as explained in the theoretical section, the estimate of $\beta$ does not only capture the effect of a particular supply shift on the wages of competing workers, it also captures the complementarity effects induced by the increase in the supply of workers with different skills and by capital accumulation (Dustmann et al., 2016b). ${ }^{35}$ Second, this approach does not depend on pre-assignment of workers to particular skill groups. It thus avoids any potential mismeasurement of the repatriate supply shock due to the possibility that repatriates downgrade their skills (Dustmann et al., 2013). Third, since the variable of interest varies at a more aggregated level than the dependent variable, the estimation of Equation 10 is expected to be more efficient (Friedberg, 2001; Boustan et al., 2010). ${ }^{36}$

Dynamics of wage adjustment. In order to investigate the wage dynamics of labor supply shocks, I estimate Equation 10 for post-migration periods. First, I estimate the effect of $\triangle m_{r}$ on the wages of pre-existing native workers between 1962-1968. I then extend the period of analysis to 1976 in order to investigate the dynamics of local wage adjustments to the repatriate supply shock measured by $\triangle m_{r}=$ Repatriates $_{r} /$ Natives $_{r}^{1968}$. I thus also estimate how $\triangle m_{r}$ affects the wages of pre-existing native workers between 1968-1976 and 1962-1976.

Measure of the labor supply shock and additional covariates. The baseline measure of the local supply shock induced by the repatriates is $\Delta m_{r}$, which is the ratio of repatriates to the pre-existing native workforce which prevails in 1968. I use the 1968 native workforce as denominator for three main reasons. First, it is very close to Hunt (1992) who takes the ratio of repatriates to the 1968 workforce to capture the repatriate supply shift. It is also similar to the other studies on the employment impact of the repatriates (Borjas and

\footnotetext{
${ }^{35}$ More generally, the parameter $\beta$ accounts for all channels through which a labor supply shock can affect local wages. Dustmann et al. (2016b, p. 53) therefore conclude that "this approach identifies a meaningful and policy relevant parameter".

${ }^{36}$ As expected, I find very similar point estimates when aggregating wages at the regional level but with larger standard errors.
} 
Monras, 2016; Clemens and Hunt, 2017). Second, this measure is computed by using the French census of 1968 which covers a very large sample of the population. The local supply shocks induced by the repatriates are therefore measured with high precision and should not lead to any attenuation bias due to measurement errors (Aydemir and Borjas, 2011). Third, the measure $\Delta m_{r}$ is consistent with factor demand theory which suggests to capture immigration-induced supply shocks by taking the total inflow of migrants as a share of the pre-existing native workforce in the post-shock period (as indicated by Friedberg, 2001; Borjas, 2003; Borjas and Monras, 2016 and shown in Section 2.1.2).

One important issue when using the native workforce in the post-shock period as denominator is the potential endogeneity of the native labor supply to the inflow of repatriates (Borjas et al., 1997; Borjas and Monras, 2016). In fact, the inflow of repatriates in a particular labor market could induce a change in the native labor supply in that market. This native response should lead to mismeasurement in the "true" supply shock induced by the inflow of repatriates and, therefore, should bias toward zero the estimates of $\beta$. As shown by Borjas and Monras (2016), a way to deal with this measurement issue is to include the log change of pre-existing native workers as a covariate in the model. In the empirical section, I therefore show that my results are robust to the inclusion of the change in the number of pre-existing native workers at the regional level over the period considered. ${ }^{37}$

In order to avoid the potential endogeneity of the native labor supply to the immigration variable, Borjas et al. (1997); Peri (2012); Peri et al. (2015); Dustmann et al. (2016b) rather use immigration as a percentage of the initial workforce to capture the immigrant supply shock. In the empirical section, I thus test the robustness of my estimates by using the following measure: $\triangle m_{r}^{1962}=$ Repatriates $_{r} /$ Native $_{r}^{1962}$. Because some studies measure the immigrant penetration by using the total workforce as denominator instead of the native workforce (Cohen-Goldner and Paserman, 2011; Dustmann et al., 2016b), I also show that my estimates are robust to using the following definition of the supply shock induced by the repatriates: $\triangle m_{r}^{1962, a l l}=$ Repatriates $_{r} /(\text { total Work force })_{r}^{1962}$.

As an additional robustness test, I also follow Basso and Peri (2015); Peri et al. (2015);

\footnotetext{
${ }^{37}$ In order to compute the log change in the number of pre-existing native workers between 1962-1968, I use the French censuses of 1962 and 1968. Since the 1975 French census cannot be used to isolate the number of pre-existing workers, I compute the log change in the number of pre-existing native workers between 1968-1976 and 1962-1976 by using the sample of workers from the wage data.
} 
Ruist et al. (2017) in including an index of sector-driven labor demand growth from Bartik (1991) in the econometric equation. This additional covariate controls for labor demand changes at the regional level. It is equal to $\triangle i n d e x_{r}=\sum_{j}\left(s_{j r}^{0} \cdot\left(\triangle E m p l_{j} / E m p l_{j}^{0}\right)\right)$, where $s_{j r}^{0}$ is the share of male employment in sector $j$ in the total employment of region $r$ at time $t_{0}$ and $\triangle E m p l_{j} / E m p l_{j}^{0}$ is the growth in male employment between $t_{0}$ and $t_{1}$ in sector $j .1$ use two sectors of activity $(j=2)$ : service and non-service occupations. ${ }^{38}$

Weighting and clustering. I estimate Equation 10 using weighted least-squares, where the weights are equal to $\left(n_{i j r}^{1} n_{i j r}^{0}\right) /\left(n_{i j r}^{1}+n_{i j r}^{0}\right): n_{i j r}^{1}$ and $n_{i j r}^{0}$ being the number of observations used to compute the dependent variables in each region-skill cell at time $t=0$ and $t=1 .{ }^{39}$ The same weights are, for instance, used in Hunt (1992); Smith (2012); Borjas and Monras (2016); Clemens and Hunt (2017); Ortega and Verdugo (2017) to estimate the causal impact of immigration on native wages from a first-difference equation. ${ }^{40}$

The standard errors from the estimated parameters of Equation 10 need to be adjusted for clustering at the regional level. In fact, wages may be correlated across skill groups within the same region, leading to correlated errors (Moulton, 1990). I thus account for the possibility of a within-group correlation of random disturbances by clustering standard errors at the regional level. ${ }^{41}$

\footnotetext{
${ }^{38}$ The results presented in Table 3 are robust to using four sectors of activity instead of two and to using wage growth instead of employment growth. The results are available upon request.

${ }^{39}$ Weighting the regressions allows (i) to achieve more precise estimates by correcting for heteroskedasticity and (ii) to provide an average wage effect that accounts for local population sizes (Solon et al., 2015).

${ }^{40}$ Dustmann et al. (2016b) rather use local employment in the pre-shock migration period as regression weight. Unless otherwise specified, all the results presented in the present paper are robust to the weight used in Dustmann et al. (2016b).

${ }^{41}$ With only $r=21$ clusters, I may have too few clusters to get unbiased standard errors (Cameron et al., 2008). More specifically, with a small number of clusters, it is likely that inference using the cluster-robust estimators provides lower standard errors than using OLS estimates. However, as I indicate in the empirical section, the baseline estimates of $\triangle m_{r}$ on the wage changes of pre-existing native workers are (i) less precise when using clustering techniques indicating that standard errors need to be adjusted for clustering and (ii) robust to the implementation of the wild cluster bootstrap method from Davidson and MacKinnon (2010).
} 


\subsection{Endogeneity of Location Choices}

The empirical strategy correlates skill-specific wages and some measure of immigrant penetration across geographical areas. As is well known from the literature, this spatial correlation approach may lead to biased results as immigrants and natives are not randomly distributed across local labor markets (Borjas et al., 1997; Dustmann et al., 2005; Lewis and Peri, 2015). First, immigrants tend to cluster in geographical areas with thriving economies. Such behaviors create a spurious positive correlation between immigration and local economic conditions. Second, "natives may adjust to the immediate impact of immigration in an area by moving their labor or capital to other localities" (Borjas, 1987, p. 15). By diffusing the impact of immigration from the affected local labor markets to the country, native internal migration can bias the estimated impact of immigration on local wages (Borjas, 2014, Chapter 6).

This section shows how I address the bias arising from the endogenous location of repatriates and investigates the impact of repatriates on native internal migration.

\subsubsection{Endogenous Location of Repatriates}

As indicated by Okkerse (2008, p. 8), exploiting natural experiments tend to overcome the problem of endogenous location as immigration is politically motivated and, therefore, exogenous to labor market conditions. ${ }^{42}$ Friedberg and Hunt (1995, p. 37) moreover indicate that the timing of the repatriation to France "was exogenous and the location of the repatriates determined to a large extent by climate (and proximity to port of arrival)."43 For these reasons, the potential (upward) bias of $\beta$ from Equation 10 introduced by the endogenous location of repatriates should be small.

As indicated in Peri (2016, p. 25), however, the suddenness of this migration episode does not necessarily guarantee the exogeneity of the spatial distribution of repatriates who could have chosen the regions with the best employment prospects and growing wages. To address this endogenity issue, I follow the existing literature in implementing an instrumental variable strategy based on three alternative instruments. A valid instrumental

\footnotetext{
${ }^{42}$ Similar arguments are given by Bratsberg and Raaum (2012); Borjas (2016).

${ }^{43}$ This is supported by Figure 2 which shows that the labor supply shock induced by the repatriates is mostly concentrated in southern regions.
} 
variable should predict differences in repatriate regional penetration for reasons unrelated to changes in local labor market opportunities.

Baseline instrument: rainfall intensity. I follow Hunt (1992) in using an instrument related to regional climatic conditions. I use the log number of rainfall days per year at the regional level. This instrument should be (i) correlated with the distribution of repatriates across regions but (ii) uncorrelated with the unobserved component of wage growth in the region. First, as shown empirically by Hunt (1992) and also suggested by French studies on the repatriates (see, e.g., Baillet, 1975; Zytnicki, 1998), climatic conditions played an important role in shaping the settlement decisions of repatriates. They mostly settle in the south of France where the climatic conditions are close to Algeria. Second, rainfall intensity is very likely to be exogenous to demand shocks or wage growth at the regional level.

I measure rainfall intensity by taking the average number of rainfall days per year for each capital's region over the 1981-2010 period. ${ }^{44},{ }^{45}$ These regional averages should better reflect the expectations of people in their settlement decisions relative to a single year with potentially extreme climatic conditions. Moreover, this average measure is unlikely to affect the explanatory power of the instrument since the rainfall intensity across French regions remained stable over the 1956-1997 period (Lebourgeois et al., 2001).

The validity of the instrument is confirmed by the first-stage estimates of the empirical analysis. They indicate a strong negative and significant relationship between the instrument (i.e., the log number of rainfall days per year) and the endogenous variable (i.e., the number of repatriates as a share of the native labor force), indicating that the repatriates tended to settle in southern regions where rainfall intensity is the lowest. Moreover, the

\footnotetext{
${ }^{44}$ These statistics are provided by "Météo France" which is the French meteorological institute.

${ }^{45}$ The capital of regions is generally the biggest city in the area. As capital, I thus use Paris for the region île-de-France, Tours for the region Centre, Dijon for the region Bourgogne, Besançon for the region FrancheComté, Le Havre for the region Haute-Normandie, Caen for the region Basse-Normandie, Lille for the region Nord-Pas-de-Calais, Amiens for the region Picardie, Metz for the region Lorraine, Strasbourg for the region Alsace, Reims for the region Champagne-Ardenne, Nantes for the region Pays de la Loire, Rennes for the region Bretagne, Bordeaux for the region Aquitaine, Poitiers for the region Poitou-Charentes, Limoges for the region Limousin, Toulouse for the region Midi-Pyrénées, Montpellier for the region Languedoc-Roussillon, Lyon for the region Rhône-Alpes, Clermont-Ferrand for the region Auvergne and Marseille for the region Provence-Alpes-Côte d'Azur.
} 
F-test of excluded instrument is always higher than 45 in the first-stage regressions. As a result, the IV estimates based on this instrument should not suffer from a weak instrument problem (Stock et al., 2002).

Alternative instrument I: distance to Algiers. The first alternative instrument is the log distance between the port of Algiers and each capital's region. This instrument should affect the location choice of repatriates across regions and should not be correlated with local economic shocks. It is inspired from several studies who use distance to border to estimate the causal impact of immigration on the labor market: Angrist and Kugler (2003) exploit distance from the Yugoslav conflict and European countries to predict immigration, Kugler and Yuksel (2008); Peri and Sparber (2009); Peri (2012); Edo and Rapoport (2017) use the distance from immigrant origin countries and U.S. States to build their instrument for immigration flows and Dustmann et al. (2016b) use distance to Czech border to instrument the relative increase in the local labor supply induced by the influx of Czech workers at the city level.

The first-stage regressions always provide larger F-tests than the lower bound of 10 suggested by the literature on weak instruments. As a result, the geographical distance between French regions and Algiers is a reasonably strong instrument.

Alternative instrument II: shift-share instrument. In order to address the bias arising from the endogeneity of immigrants' location choices, the literature on migration generally exploits the historical distribution of immigrants across local labor markets as instrument (Altonji and Card, 1991; Card, 2001; Cortes, 2008; Peri, 2012; Borjas, 2014). In their studies on the labor market impact of the repatriates from Algeria, Hunt (1992); Borjas and Monras (2016); Clemens and Hunt (2017) use a similar instrument to predict their spatial distribution. This instrument is based on the idea that past settlements of immigrants can predict subsequent flows across locations through network effects, while past immigrant concentrations should be uncorrelated with current unobserved economic shocks (Ruist et al., 2017). The network effect is expected to be particularly strong between immigrants with the same cultural, linguistic and educational background (Dustmann et al., 2005).

I exploit this "network justification" and use the spatial distribution of of Algerian-born 
people for a given origin-education group to predict the regional distribution of repatriates from that origin-education group. I use four origin groups (French by birth and born in France, French by birth and born in Algeria, Algerian by birth and others as discussed in Section 3) and four education groups (high, medium, low and very low as discussed in Section 4.1.3). I exploit the 1962 French census to infer the initial number of Algerian-born people (aged 18-64) residing in France before the exodus for each origin-education group across regions. I then compute the imputed number of repatriates (i.e., Repatriates ${ }_{r}^{1968}$ ) for each region by multiplying the spatial distribution of Algerian-born people from a given origin-education group by the total number of repatriates from that group, as follows:

$$
\widehat{\text { Repatriates }_{r}}=\sum_{n} \sum_{i} \frac{\text { Algerian }- \text { born }_{i r}^{n}(1962)}{\text { Algerian }- \text { born }_{i}^{n}(1962)} \times \text { Repatriates }_{i}^{n} .
$$

Because the current native labor supply Natives ${ }_{r}^{1968}$ could be endogenous to the inflow of repatriates, I also predict the number of pre-existing natives across French regions as follows:

$$
\widehat{\text { Natives }}_{r}^{1968}=\sum_{i} \frac{\text { Natives }_{\text {ir }}(1962)}{\text { Natives }_{i}(1962)} \times \text { Natives }_{i}(1968)
$$

I exploit the French census of 1962 to infer the pre-exodus spatial distribution of natives by using four education groups (high, medium, low and very low as discussed in Section 4.1.3). I can finally compute the following shift-share instrument:

$$
\triangle \hat{m}_{r}=\text { Re } \widehat{\text { patriates }} / \widehat{\text { Native }} s_{r}^{1968} .
$$

The first-stage estimates indicate a strong positive correlation between the instrument and the ratio of repatriates to pre-existing natives - the F-test of exclusion is above 300.

The instrument $\Delta \hat{m}_{r}$ is more powerful than the two other ones (i.e., rainfall intensity and distance to Algiers). However, as is well known from the literature, the shift-share instrument requires strong identifying assumptions (Hanson, 2009; Borjas, 2014; Lewis 
and Peri, 2015; Ruist et al., 2017). In fact, this instrument would be invalid if, for instance, the local economic conditions that influence immigrant settlement patterns are persistent over time. Although more powerful, $\Delta \hat{m}_{r}$ is also less likely to satisfy the IV exclusion restriction than the other instruments. However, the use of the shift-share instrument may still be informative on the causal impact of migration on wages since "in some scenarios, it will be preferable, in terms of learning about $\beta$, to use a strong instrument that may not satisfy the exclusion restriction rather than a weak one that does" (Conley et al. 2012, p. 268).

Clemens and Hunt (2017) underline an additional limitation of the shift-share instrument. The fact that the statistical relationship between $\Delta m_{r}$ and $\Delta \hat{m}_{r}$ is mostly driven by their denominator can lead to spurious correlation between the instrument and the endogenous variable. To address this potential issue, I follow Clemens and Hunt (2017)'s suggestion and show that my results are robust to the specification correction proposed by Kronmal (1993). The idea is to split the ratio $\Delta m_{r}$ into the numerator and the denominator, apply a log transformation and instrument the log number of repatriates by the log predicted number of repatriates based on Equation 11.

\subsubsection{Endogenous Location of Non-Repatriates}

Following the two empirical strategies proposed by Borjas (2006) and Peri and Sparber (2011a), Appendix-Table 11 reports the estimated impact of repatriates on the internal migration of pre-existing natives. I do not find any evidence that the regional supply shocks induced by the inflow of repatriates affected the mobility of pre-existing natives across regions between 1962 and 1968. ${ }^{46}$ This result is consistent with Hunt (1992) who shows that the repatriates did not affect migration across French departments (which are smaller geographical units than regions). As a result, the estimated impact of repatriates on the change in regional wages between 1962 and 1968 are not biased by native internal migration. ${ }^{47}$

\footnotetext{
${ }^{46}$ Because the 1975 census does not allow me to disentangle the pre-existing workers from the repatriates, I cannot extend this analysis to the period 1968-1975.

${ }^{47}$ More generally, as indicated by Borjas (2016); Peri (2016), the estimated short-run wage effects of immigration should not be contaminated by local labor market adjustments when exploiting sudden and unexpected influx of people.
} 
The left-hand side of Appendix-Table 11 is based on the strategy proposed by Borjas (2006). It investigates the impact of repatriates on the out-migration rate of pre-existing natives with education $i$ living in region $r$ between 1962 and 1968. As proposed by Borjas $(2006,2014)$, I compute the out-migration rate by dividing the total number of out-migrants from region $r$ and the total number of natives living in that region in 1962. ${ }^{48}$ The right-hand side of Appendix-Table 11 is based on the strategy proposed by Peri and Sparber (2011a) and provides a direct test for displacement. I precisely follow their preferred specification and regress the change in the pre-existing native population standardized by the initial native population on the number of repatriates standardized by the initial native population. 49,50

All regressions presented in Appendix-Table 11 include education fixed effects. I also cluster the standard errors at the regional level and weight each regression by $\left(n_{i r}^{1968} n_{i r}^{1962}\right) /\left(n_{i r}^{1968}+n_{i r}^{1962}\right.$ where $n_{i r}^{1968}$ and $n_{i r}^{1962}$ represent the number of pre-existing natives in each region-education group in 1968 and 1962, respectively.

I report the estimated impact of repatriates on the mobility and displacement of preexisting male natives, high educated male natives and female natives. ${ }^{51}$ The first specification reports OLS estimations, while the other report IV estimations using rainfall intensity (specification 2), distance from Algiers (specification 3) and past immigration patterns (specification 4) as instruments. As already emphasized in Section 5.2, the F-statistic indicates that the IV estimates do not suffer from a weak instrument problem. The IV estimates are always insignificant, indicating that the regional penetration of repatriates did not lead to native outflows between 1962 and 1968. As a result, the wage elasticity to immigration estimated over the $1962-1968$ period is not biased by native reallocation across regions.

\footnotetext{
${ }^{48}$ The 1968 census information not only provide individuals' region of residence at the time of the census, but also on first January 1962 (before the exodus from Algeria). I thus use the 1968 census to infer the number of out-migrants and use the 1962 census to infer the total number of natives living in the "original" region of residence (that is, the region of residence in 1962).

${ }^{49}$ I use the French censuses of 1962 and 1968 to compute the dependent and explanatory variables.

${ }^{50}$ Under this specification, the estimated coefficient translates into the number of natives who respond to one extra repatriate in the region. This specification is very close to Card (2007) and implemented, for instance, in Monras (2015a); Sá (2015).

${ }^{51}$ I use the subgroup of high educated natives as geographic mobility is a more important adjustment margin for skilled workers (Molloy et al., 2011; Sá, 2015).
} 


\subsection{Other Identification Issues}

An additional source of bias may come from sampling errors in the measure of $\Delta m_{r}$ due to small sample sizes (Aydemir and Borjas, 2011). Indeed, any measurement error in the computation of regional immigrant penetration should lead to an attenuation bias in the estimated wage response to the influx of repatriates. However, this potential bias should be very limited in the present paper since I measure the ratio of repatriates to natives at the regional level (rather than departments or smaller geographical units) and use the very large 1968 census extract which forms a 25 percent random sample of the population. In any case, the IV strategy should correct for the attenuation bias in estimating the wage effects of immigration (given that the instrument should be uncorrelated with measurement error). ${ }^{52}$

In a revisit of the labor market impact of several historical refugee flows, Borjas and Monras (2016, p. 21) argue that "the self-selection of immigrants contaminates the measured wage impact of immigration." By comparing the returns to skill between their home and other potential destination countries, individuals may be willing to migrate to countries with the highest returns to skill. This sorting into skill-country groups may bias the estimated wage effect of immigration. The present study is, however, impervious to this identification issue since the repatriates who moved to France in 1962 was forced to leave Algeria. In order to mitigate any bias arising from self-selection issues, I also compute $\triangle m_{r}$ by restricting my attention to the 91.1 percent of repatriates who were French by birth (since they were forced to move to France after independence). I estimate their impact on the wages of pre-existing native workers and find that this alternative measure of the repatriate supply shock does not affect any conclusions of this paper. ${ }^{53}$

\footnotetext{
${ }^{52}$ In other contexts, the measurement error in the computation of immigrant shares might be strengthened if immigrants downgrade their skills and accept jobs that require lower education than they have (Borjas and Monras, 2016). As noticed in Section 5.1, the main empirical strategy used in this paper does not require any pre-allocation of immigrants to skill groups.

${ }^{53}$ The results are available upon request.
} 


\section{Main Empirical Results}

\subsection{Main Estimates}

Table 3 reports the estimated effects of the supply shock induced by the repatriates on the wage changes of pre-existing native workers between 1962 and 1968, between 1968 and 1976 and between 1962 and 1976. For each period, I report two sets of regressions. The first set reports the baseline estimates of $\beta$ from Equation 10. The second set includes the index of sector-specific growth to control for labor demand changes at the regional level and the log change in the number of pre-existing native workers to control for the endogenous change in the size of the pre-existing workforce (as discussed in Section 5.1).

Each regression is based on a sample of 168 observations (21 regions, 4 education groups and 2 occupations). The first specification reports OLS estimations, while the other specifications report IV estimations with rainfall intensity (specification 2), distance to Algiers (specification 3) and past settlement patterns among Algerian-born people (specification 4) as instruments. For each IV regressions, I provide the first-stage estimates. In line with existing studies on the repatriation from Algeria to France, ${ }^{54}$ the density of repatriates across regions is negatively correlated with rainfall intensity and distance to Algiers and positively correlated with the presence of earlier waves of Algerian-born people. As already discussed in Section 5.2, the F-statistics indicate that the IV estimates do not suffer from a weak instrument problem. Under the plausible assumption that local economic shocks are uncorrelated with rainfall intensity, distance from Algiers and past immigration patterns, the IV estimates have a causal interpretation.

Between 1962 and 1968, each specification indicates that the supply shock induced by the repatriates had negative and significant effects on the wage of native workers. This is consistent with standard economy theory which predicts that a positive labor supply shock should reduce the average wage of workers in the short-run. More specifically, the OLS estimate implies that a 1 percentage point increase in the workforce due to the inflow of repatriates decreases the average wage of natives by around 1.3 percent. Given the

\footnotetext{
${ }^{54}$ See, e.g., Hunt (1992); Okkerse (2008); Borjas and Monras (2016) for economic studies and McDonald (1965); Baillet (1975); Zytnicki (1998) for historical studies.
} 
average size of the supply shock (which is about 1.8 percent for men), this magnitude indicates that the inflow of repatriates decreased the average wage of natives by 2.3 percent. Consistent with an upward bias in the OLS estimates, the IV estimations produce more negative wage effects. They imply that the native wage response to a 1 percentage point increase in the workforce due to the repatriation is between -1.2 and -2.1 percent. ${ }^{55}$

It is important to put this negative wage response into perspective with respect to the French economic conditions. Over the 1962-1968 period, France went through a booming period (5 percent GDP growth per year) leading to an substantial increase in the regional wages of pre-existing native workers, as shown in Appendix-Table 13. Thus, the estimated negative effects reported in Table 3 do not imply a decline in native wages but rather indicate that the regions which received the most repatriates were the ones where wages grew the least.

Over the 1968-1976 period, I find that the supply shock induced by the inflow of repatriates had positive effects on the wages of native workers. The estimates imply that a 1 percentage point increase in the workforce due to the inflow of repatriates increases the regional wages of natives by between +0.2 and +1.7 percent. Given the size of the supply shock (which is about 1.8 percent), these estimates imply a positive change in native wages by around 0.4 to 3.1 percent due to the repatriation between 1968 and 1976 . This positive effect is consistent with standard economic theory which predicts that some adjustment mechanisms should operate in the medium-run after the short-run decline in wages (as we have seen in Section 2).

In column 3, none of the estimates are significant. The positive wage effect induced by the repatriates in the medium-run offsets the negative short-run wage effects. The estimates thus indicate that regional wages returned to their pre-shock level after about

\footnotetext{
${ }^{55}$ As discussed in Section 5.1, I may have too few clusters to get unbiased standard errors. In AppendixTable 12, I perform some robustness tests to show that the baseline IV estimated effects (specification 2) are less precise when using clustering techniques. This indicates that the standard errors of the parameter estimates tend to be biased downward and, therefore, need to be adjusted for clustering. Appendix-Table 12 also follows Cameron et al. (2008)'s suggestion and perform wild cluster bootstrap methods, allowing for clustering at the regional level. I bootstrap the standard errors by using the wild-bootstrap procedure proposed by Davidson and MacKinnon (2010) and 10,000 replications. The 95\% confidence intervals of the estimated coefficients when using bootstrap methods are close to the baseline confidence intervals. This shows that the previous results are robust to bootstrapped standard errors which allow for clustering at the regional level.
} 
15 years. The recovery of local wages from positive supply shocks is consistent with standard economic theory (as we have seen in Section 2).

\subsection{Robustness Checks}

This section shows that the previous econometric results are robust to alternative estimation strategies, definitions of the repatriate supply shock and samples.

\subsubsection{Implementing the Specification Correction by Kronmal (1993)}

As indicated by Clemens and Hunt (2017), the fact that the shift-share instrument and the endogenous variable have a common divisor can generate spurious correlation between the ratios $\triangle m_{r}$ and $\triangle \hat{m}_{r}$ and bias the second-stage IV estimates. I thus follow Clemens and Hunt (2017)'s suggestion and apply the specification correction proposed by Kronmal (1993). In this regard, Table 4 shows that the estimated wage effects induced by the inflow of repatriates are robust to decomposing the ratio $\Delta m_{r}$ and instrumenting the log of repatriates by the log of predicted repatriates based on past immigrant settlement patterns (as defined in Equation 11).

The OLS and IV results from Table 4 show that the log number of repatriates decreased the wages of pre-existing native workers between 1962-1968. The estimated coefficient suggests that a 1 percentage point increase in labor supply decreases the regional wage of native workers by between 1.6 to 2.2 percent. ${ }^{56}$ This magnitude is similar to the baseline results presented in Table 3.

Table 4 also shows that the repatriates had positive effects on the wages of native workers between 1968-1976, while the wage effect between 1962-1976 are insignificant. In accordance with the baseline results of Table 3, these effects indicate that regional wages recover from the repatriate supply shock after about 15 years.

\footnotetext{
${ }^{56}$ In order to convert the estimated coefficient into an elasticity, it has to be multiplied by $(1-m) / m$, with $m=M / N$. The value of $m$ for the sample of men is $m=0.018$. See Clemens and Hunt (2017) for further details and a formal derivation.
} 


\subsubsection{Alternative Measures of the Supply Shock and Alternative Samples}

Table 5 reports the OLS and IV estimates of $\beta$ from Equation (10) for various specifications using rainfall intensity as the baseline instrument.

Specifications 1 and 2 respectively use $\Delta m_{r}^{1962}$ and $\Delta m_{r}^{1962, \text { all }}$ as alternative measures of the repatriate supply shock (as defined in Section 5.1). Specification 2 uses the ratio of repatriates to the native workforce in 1962 and specification 3 uses the ratio of repatriates to the pre-existing workforce in 1962. The results from these specifications reinforce the previous conclusions: they report significant negative wage effects in the short-run (19621968), positive wage effects in the medium-run (1968-1976) and no significant effect over the whole period (1962-1976).

Specifications 3 and 4 use alternative samples to compute wage changes for preexisting native workers. Specification 3 removes from the sample of native workers those working in the public sector since it may be less competitive than the private one and, therefore, more subject to downward wage rigidities (Edo, 2015). In specification 4, I follow Borjas (2016); Borjas and Monras (2016) and limit the wage sample to native workers aged 25-55 as school and retirement decisions could be endogenous to the inflow of repatriates. The estimated wage effects due to the inflow of repatriates are not sensitive to these alternative samples.

Specifications 5 to 7 show that the baseline results are robust to alternative skill-cell structures to compute the dependent variable. Specifications 5 and 6 respectively use three and six education groups (instead of four) to compute the change in native wages at the skill-region level (dealing respectively with 126 and 252 observations for regressions). Specification 7 defines the change in native wages at the education-region level (dealing with 84 observations for regressions). Although they have fewer observations for regressions, specifications 5 and 7 allow me to increase the number of observations per cell to compute the average wage of native workers. The results from specifications 5 to 7 support the previous findings.

Specification 8 focuses on the sample of women to study how the influx of female repatriates affected the wages of pre-existing female natives. Although interesting, such analysis can be subject to important identification issues (Borjas, 2016). One important issue is due to the increase in the participation rate of pre-existing native women between 
1962 and 1968 which is, moreover, heterogeneous across regions (see Appendix-Table 13). ${ }^{57}$ In fact, the entry of large numbers of women into the workforce changes the sample composition of pre-existing female workers over time, thereby contaminating wage evolutions and the estimated wage impact of immigration on female wages. With this caveat in mind, the results from specification 8 are consistent with the previous conclusions for the sample of men. Although the significance and magnitude of the estimated wage effects differ from the baseline sample of men, I find that the regional average wage of pre-existing female native workers decline in the first years in response to the inflow of repatriates, before returning to their pre-shock level 15 years after.

\subsection{Reconciling my Results with Hunt (1992)}

The previous econometric results indicate that the influx of repatriates had a detrimental impact on the regional wage of natives over the 1962-1968 period. The estimates imply an elasticity of wages with respect to the number of workers between -1.0 and -2.0 , meaning that a 1 percent increase in the size of the workforce due to the inflow of repatriates in a particular region reduces the wage of pre-existing native workers in that region by 1 to 2 percent. This wage reaction is stronger than the one found by Hunt (1992, Table 4, p.567) who shows a wage elasticity equals to -0.7 using OLS and -0.8 using a GLS estimation. ${ }^{58}$

The gap between our estimates can be explained by three main differences. First, Hunt (1992) uses a smaller geographical area to study the labor market impact of the repatriates and could therefore underestimate the "true" wage impact induced by the supply shock due to local labor market adjustments. ${ }^{59}$ Second, the wage elasticity from Hunt (1992, p.567, Table 4) does not account for the potential endogenous spatial distribution of repatriates to

\footnotetext{
${ }^{57}$ The participation rate of pre-existing native women increased by 4.2 percentage points from 37.0 in 1962 to 41.2 percent in 1968 . The participation rate decreased for pre-existing native men by 1.4 percentage points from 89.6 in 1962 to 88.2 percent in 1968.

${ }^{58}$ While the GLS estimation provides a point estimate that is significant at 5 percent, the OLS estimate is not significant. This difference in precision is consistent with the fact that GLS estimator is, in principle, more efficient than OLS estimator in the presence of heteroskedastic and serially correlated errors (Angrist and Pischke, 2008; Solon et al., 2015). Notice that in the regression table produced by Hunt (1992, p.567, Table 4), the estimated coefficients from first-difference estimations have to be multiplied by ten to convert them into an elasticity.

${ }^{59}$ Hunt (1992) uses French departments, while I use regions to define local labor markets.
} 
local wages. In particular, they should be interpreted as lower bounds of the "true" wage impact if the repatriates were allocated to regions which experienced positive economic shocks. ${ }^{60}$

Third, from the wage data used by Hunt (1992, p. 566), "it is not possible to distinguish composition effects from effects on the indigenous French as no salary data are available on the repatriates separately." Yet, the changes in the sample composition created by the influx of repatriates into France (who are relatively more educated than pre-existing natives) could contaminate the post-1962 wage trend and bias the measured wage impact induced by the supply shock. Given the relatively high education of repatriates, their wages were likely to be higher than the average level. ${ }^{61}$ The inclusion of repatriates in the wage sample should thus increase the average wage in the affected regions, inducing a potential spurious positive correlation between the inflow of repatriates into a particular region and the change in average wage in that region. As a result, the composition effect introduced by the inclusion of repatriates in the wage sample should attenuate the negative wage impact induced by the supply shock.

In order to evaluate the bias induced by this composition effect, I re-estimate the wage impact induced by the repatriates between 1962-1968 without excluding from the wage sample the repatriates and other post-1962 entry into local labor markets. This strategy allows me to deal with an alternative wage sample that is very close to the one used by Hunt (1992). After re-estimating the baseline OLS specification from Table 3 (row 1), I find an estimated coefficient equal to -0.8 (with a corresponding Student's t-test equal to -2.5). This point estimate is identical to the baseline estimate found by Hunt (1992). This finding reconciles my results with Hunt (1992) and reinforces the previous conclusions. It also suggests that the composition effects due to the inclusion of the repatriates into the wage sample lead to underestimate the true short-run impact of repatriates on wages. ${ }^{62}$ It is therefore crucial to account for the composition effects created by the large entry of

\footnotetext{
${ }^{60}$ In employment regressions, Hunt (1992, Table 3, p.565) finds that the positive impact of repatriates on native unemployment is stronger when using IV estimation techniques than simple OLS. This discrepancy suggests that her negative estimates on the wage impact of immigration is also likely to be underestimated.

${ }^{61}$ This cannot be tested since my wage data do not allow me to disentangle the repatriates from other post-1962 entry into the workforce.

${ }^{62}$ The upward bias in the estimated effect of repatriates on regional wages is consistent with the fact that the repatriates were relatively more educated than the pre-existing native workforce.
} 
repatriates (and other post-1962 waves of migrants) in the French labor market.

Moreover, I re-estimate the wage impact induced by the repatriates between 19621968 with this alternative sample by implementing an IV strategy with rainfall intensity as instrument. I find a negative coefficient equal to -1.5 (with a corresponding Student's ttest equal to -2.2). The estimated wage effect almost doubles (from -0.8 using OLS to -1.5 using IV). Correcting for endogeneity thus provides a stronger negative impact on wages. This finding is consistent with the tendency of immigrants to settle in areas with fast growing labor demand. It is also in line with Hunt (1992) who finds a stronger positive impact of repatriates on unemployment rate when using an IV strategy.

\subsection{Comparison with Other Studies}

The short-run wage elasticity with respect to the number of workers implied by the baseline IV estimate is -1.9 . This estimate corresponds to a total labor demand elasticity of -0.5 (as opposed to constant-output elasticity). ${ }^{63}$ This value is exactly the same as the mean value of labor demand elasticity derived from the meta-analysis by Lichter et al. (2015). ${ }^{64}$ Despite this similarity, the short-run wage elasticity (between -1.0 and -2.0) is stronger than in several cross-area analysis on the wage impact of immigration (Okkerse, 2008; Pekkala Kerr and Kerr, 2011; Clemens and Hunt, 2017). ${ }^{65}$ Two main reasons can explain this discrepancy.

On the one hand, the repatriates are very likely to be perfect substitutes to natives, as explained in Section 3. The short-run impact of the labor supply shift induced by the repatriates on local wages is expected to be more detrimental than in other migration context where immigrants are relatively poor substitutes for natives.

\footnotetext{
${ }^{63}$ By the law of demand, the total elasticity should exceed the constant-output elasticity of labor demand in absolute terms since it additionally accounts for "scale effect" (Hamermesh, 1993).

${ }^{64}$ As shown in their meta-regression analysis, the magnitude of the labor demand elasticity is strongly heterogeneous across empirical studies depending on the definition of the labor demand elasticity (total $\mathrm{v}$. constant-output elasticity), underlying theoretical model (structural-form v. reduced form model), dataset (firm-, industry- v. country-level, etc.) and workforce characteristics (male v. female and high skilled v. low skilled workforce).

${ }^{65}$ It is, however, consistent with the U.S. studies by Altonji and Card (1991) who show that a 1 percentage point increase in the fraction of immigrants in a metropolitan area reduces the wage of white (black) male high school dropouts by around $-1.1(-1.9)$ percent and Goldin (1994) who finds a wage elasticity to immigration by about 1 to 1.5 at the beginning of the twentieth century.
} 
On the other hand, as noted by Peri (2016, p. 25), "unexpected [migration] episodes often allow less time for adjustment on the margins, and their short-run effect may be larger than for expected episodes." The exogenous timing of the repatriation from Algeria did not allow labor demand conditions to adjust immediately and, therefore, the inflow of repatriates had strong adverse wage effects in the short-run. This interpretation is consistent with the short-run wage effects reported by Borjas (2016); Ruist et al. (2017) which are stronger than the ones reported in several cross-area analysis on the wage impact of immigration. By exploiting the influx of Cuban refugees from the port of Mariel in Miami, Borjas (2016) finds a short-run elasticity of wages between -0.5 and -1.5 for the group of low-skill workers. Using non-experimental U.S. data to isolate the short-run effects of immigration on local wages to longer-run effects, Ruist et al. (2017) find a shortrun elasticity of wages to immigration of between -0.9 and -1.3 .

The econometric results reported in Tables 3 and 5 also show that the wage elasticity to the number of workers is positive over the 1968-1976 period. This positive effect induced by the repatriates in the medium-run fully compensates the adverse wage effects in the short-run. The regional wages of native workers thus returned to their pre-shock level 15 years after. As emphasized in Section 2.2, this rate of adjustment is consistent with several studies indicating that regional wage adjustments to local shocks generally take more than a decade (Blanchard et al., 1992; Borjas, 2016; Amior and Manning, 2015; Monras, 2015a; Ruist et al., 2017).

\section{The Impact of Repatriates on Relative Wages}

This section investigates the distributional consequences induced by the inflow of repatriates across education groups. Based on the theoretical Equation 9 (Section 2.1.1), I derive the following relative wage empirical equation:

$$
\triangle \log \left(\frac{w_{H}}{w_{L}}\right)_{j r}=\alpha+\beta \cdot \triangle m_{r}+\delta_{j}+\triangle \epsilon_{j r} .
$$

The dependent variable is the change in the log wage of high educated relative to non- 
high educated pre-existing native workers in occupation $j$ and region $r$. The education group $H$ is composed of natives who have a high education level, while the education group $L$ is composed of natives who have a medium education or less. Equation 14 also includes an occupation dummy $\delta_{j}$ and contains an error term $\triangle \epsilon_{j r}$. Because the dependent variable is the change in the relative wage of high educated to non-high educated workers, factors that affect symmetrically the labor demand for high and non-high educated workers are removed from the equation.

Table 6 reports the estimates of $\beta$ from Equation 14 by using relative wage variations between 1962-1968 and 1962-1976. I perform OLS and IV estimations using rainfall intensity as the baseline instrument. As earlier, I use $\Delta m_{r}$ and $\Delta m_{r}^{1962}$ to measure the regional supply shocks induced by the repatriates. They respectively uses the current and initial native workforce as denominator.

Specification 1 uses the change in the log wage of high educated to non-high educated pre-existing native workers as dependent variable. I then decompose the group of non-high educated workers and take the relative wage of high educated to medium educated workers (specification 2), to low educated workers (specification 3) and to very low educated workers (specification 4). In all regressions, I cluster the standard errors at the regional level and weight each regression by $\left(n_{j r}^{0} n_{j r}^{1}\right) /\left(n_{j r}^{0}+n_{j r}^{1}\right)$, where $n_{j r}^{0}$ and $n_{j r}^{1}$ represent the number of pre-existing native workers used to compute the dependent variables in each region-occupation cell in $1962(t=0)$ and 1968 or $1976(t=1)$, respectively.

Between 1962 and 1968, the estimates indicate that the inflow of repatriates decreased the relative wage of high educated native workers. This empirical result is consistent with the theoretical Equation 9 which predicts that the skill groups which experienced the largest inflow of repatriates (here, high educated workers as immigration is relatively high educated) suffered the largest decline in wages. The negative estimated impact of repatriates on relative wages is heterogeneous with respect to the comparison group considered. Specifications 2 and 3 indicate weaker negative effects than in specification 3 where the dependent variable is the change in the relative wage gap between high and very low educated workers. This asymmetric result across education groups is consistent with the theoretical Equation 9 which indicates that the impact of immigration on relative wages depends on the substitution elasticity between skill groups. Since the degree of 
substitutability between high and very low educated workers should be the lowest, the decline in the relative wage of high to very low educated workers is the strongest.

Over the whole period 1962-1976, the estimated relative wage effects are still negative but weaker and less significant for each specification. This result points to a persistent reduction in wage inequality between high and very low educated native workers. It also indicates that the relative wage of high educated workers tended to recover over time. Such recovery is not consistent with the theoretical Equation 14 which predicts that the relative wage effect of immigration across skill groups should be invariant over time. The theoretical model used in Section 2.1.1, however, assumes closed local labor markets. It might thus be the case that the recovery in the relative wage of high educated workers has been due to cross-regional adjustments. ${ }^{66}$ For instance, high educated native workers could have responded to the inflow of repatriates by moving across regions between 19681976. Such response would be consistent with the fact that geographic mobility is a more important adjustment margin for skilled workers, as migration rates rise with education (Molloy et al., 2011; Amior and Manning, 2015).

\section{The Wage Impact of Repatriates at the Region-skill Level}

This section provides an additional analysis on the distributional effects induced by the repatriates by estimating their impact on the wages of pre-existing native workers with similar skills. It may be the case that the skill groups which experienced the largest supply shocks would be the ones where wages grew the least (or fell the most), at least in the short-run. I thus implement a skill-cell analysis, inspired from Card (2001); Borjas (2003) and estimate the following equation:

$$
\triangle \log w_{i j r}=\alpha+\beta \cdot \triangle m_{i j r}+\delta_{i j}+\triangle \epsilon_{i j r}
$$

where $\triangle \log w_{i j r}$ is the change in the wage of pre-existing native workers between two

\footnotetext{
${ }^{66}$ Cohen-Goldner and Paserman (2011); Borjas (2016) also find no persistent distributional effects in response to the high-skill immigration experienced by Israel in 1990 or low-skill immigration experienced by the U.S. in 1980.
} 
points in time in region $r$, occupation $j$ and education $i . \Delta m_{i j r}$ is the change in the preexisting native labor supply due to the influx of repatriates from Algeria within region $r$ and skill group $i, j$. As earlier, I use 21 regions, 4 education and 2 occupation groups. This equation differs from the baseline Equation 10 where the immigrant penetration is measured at the region-skill group level. I include skill fixed effects to control for unobserved demand shocks at the skill group level. $\triangle \epsilon_{i j r}$ is an error term. Borjas and Monras (2016); Clemens and Hunt (2017) use a very similar strategy to investigate the impact of repatriates on the unemployment rate of natives within the same region-skill group. ${ }^{67}$

Equation 15 implies that the parameter $\beta$ is identified from changes within skill groups across regions. It is important to notice that this empirical strategy holds the labor supply in all other skill groups and the capital stock constant. By neglecting cross-group complementarities and capital-stock adjustments, the parameter $\beta$ thus identifies the direct partial effects of immigration on the wages of similarly skilled natives (Ottaviano and Peri, 2008, 2012; Dustmann and Glitz, 2015).

One important identification issue is related to the endogenous distribution of repatriates across region-skill groups. To address this issue, I use an instrument based on past immigration patterns. I use the distribution of Algerian-born people for a given origin-skill group across French regions to allocate the repatriates from that origin-skill group across regions. As in Section 5.2.1, I use four origin groups: French by birth and born in France, French by birth and born in Algeria, Algerian by birth and others. I also predict the current number of natives based on the 1962 spatial distribution of natives for each skill group. The instrument $\triangle \hat{m}_{i j r}$ is thus computed as follows: 68

$$
\triangle \hat{m}_{i j r}=\text { Repatriates }{ }_{i j r} / \widehat{\text { Native }} s_{i j r}^{1968}
$$

where,

\footnotetext{
${ }^{67}$ As in Borjas and Monras (2016); Clemens and Hunt (2017), I do not include region fixed effects in the empirical analysis. Their inclusion considerably reduces the power of the instrument and makes the estimated coefficients very unstable.

${ }^{68}$ Because the measure of immigrant penetration $\Delta m_{i j r}$ is defined at the region-skill group level, I cannot use rainfall intensity or distance from Algiers as alternative instruments.
} 


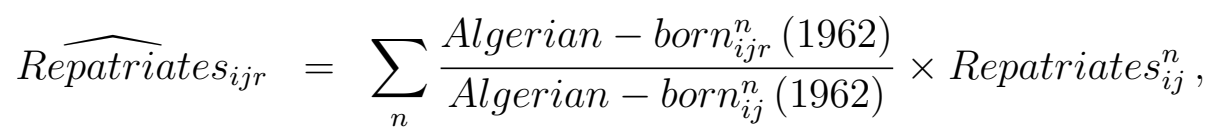

and,

$$
\widehat{\text { Native }}_{i j r}^{1968}=\frac{\text { Natives }_{i j r}(1962)}{\text { Natives }_{i j}(1962)} \times \text { Natives }_{i j}(1968) .
$$

As indicated by Clemens and Hunt (2017, p. 15), "a potential weakness of this instrumental variables approach lies in the fact that the native population of each region changes little over the short time periods in question, thus both the instrument and the endogenous variable have a common divisor". In fact, the identifying information of the instrument could only be driven by the denominator, leading to spurious correlation between $\triangle m_{i j r}$ and $\triangle \hat{m}_{i j r}$. Although this potential limitation is mitigated by the fact that I also predict the current number of natives (see Equation 18), I address this identification problem by following Clemens and Hunt (2017)'s suggestion and implementing the Kronmal (1993)'s correction. As discussed in Section 5.2.1 and already implemented in Section 6.2.1, this correction splits the ratio $\triangle m_{i j r}$ into the numerator and the denominator, apply a log transformation and instrument the log number of repatriates by the log predicted number of repatriates.

Preliminary analysis. Figure 3 provides a preliminary look at the correlation between the ratio of repatriates to pre-existing natives and the change in the log wage of preexisting native workers between 1962-1968. Each point represents a region-educationoccupation group. This figure indicates a negative and significant relationship between the inflow of repatriates and wage changes: the estimated coefficient is -0.78 (with a corresponding Student's t-test equal to -1.72). The plot also suggests that the regression line is not driven by any particular outliers.

Figure 4 reproduces the same exercise but defines skill groups at the education-age 
level. ${ }^{69}$ I use three age groups: from 18 to 30,30 to 44 and 44 to 64 (as defined in Table 2). Each point represents a region-education-age group. This figure indicates a negative and significant relationship between the inflow of repatriates and wage changes: the estimated coefficient is -1.10 (with a corresponding Student's t-test equal to -2.29).

These correlations indicate an "own" wage elasticity to immigration of between -0.78 and -1.10 , implying that a 1 percent increase in the workforce due to the inflow of repatriates within a region-skill group reduces the wage of natives in that group by 0.8 to 1.1 percent. This wage elasticity is similar to the one found by Llull (2017); Monras (2015a) after instrumentation for the U.S., Edo (2016) for France when focusing on native workers covered by fixed-term contracts and Borjas and Monras (2016) when revisiting the wage impact of the Mariel Boatlift.

This preliminary analysis suggests that the wages grew fastest for the native workers in those skill groups that have experienced the lowest labor supply shocks. The remainder of this section tests the robustness of this preliminary analysis to the inclusion of skill fixed effects, alternative definitions of skill groups and to an IV estimation strategy.

Econometric results. Table 7 reports the empirical results of the effect of repatriates on wage changes for pre-existing male native workers with similar skills between 1962-1968 and 1962-1976. I use two measures of immigrant penetration $\Delta m_{i j r}$ and $\Delta m_{i j r}^{1962}$. They respectively uses the current and initial native workforce as denominator. I perform OLS and IV estimations using past immigration patterns as instrument (see Equation 16). The first stage IV regressions report F-tests of excluded instruments of between 40 and 260. This suggests that the IV second-stage estimates are very unlikely to suffer from a weak instrument problem. I weight each regression by $\left(n_{i j r}^{0} n_{i j r}^{1}\right) /\left(n_{i j r}^{0}+n_{i j r}^{1}\right)$, where $n_{i j r}^{0}$ and $n_{i j r}^{1}$ represent the number of pre-existing native workers used to compute the dependent variables in each region-skill cell in $1962(t=0)$ and 1968 or $1976(t=1)$, respectively.

Specification 1 uses the baseline sample with 21 regions, 4 education groups and 2 occupation groups. Specification 2 uses the sample with 21 regions, 6 education groups

\footnotetext{
${ }^{69}$ This alternative skill-cell definition relies on the very influential study by Borjas (2003). This alternative definition should attenuate the possibility that natives may respond to immigration by moving their labor supply across skill groups. It is indeed impossible for natives to escape immigrant competition by moving across age groups.
} 
and 2 occupation groups. Instead of using four education groups, Specification 2 uses six narrower education groups to test the possibility of an educational downgrading among repatriates. In fact, using a labor market segmentation along four education levels could fail to appropriately identify groups of workers competing for the same jobs. Hence, a more detailed education partition with six education groups should allow to deal with the impact of repatriates on equally skilled native workers.

Specification 3 relies on the strategy by Borjas and Monras (2016); Clemens and Hunt (2017) by defining skill groups at the education level only. It thus uses a sample with 21 regions and 4 education groups. This classification has two main advantages. It avoids any bias due to native movements across occupation groups and reduces any potential attenuation bias by increasing the number of observations per skill groups (Aydemir and Borjas, 2011). Instead of occupation groups, specification 4 relies on Borjas (2003) and uses three age groups to define skill groups (from 18 to 30,30 to 44 and 44 to 64 ). This specification thus uses a sample with 21 regions, 4 education groups and 3 age groups. ${ }^{70}$

Between 1962 and 1968, the estimated coefficients are always negative and significant. The implied wage elasticity to immigration from the IV estimates is between -1.0 and -2.5. This range is close to the previous estimates (from -1.0 to -2.0 ) which exploit variation across regional supply shocks. This suggests that cross-group complementarities tend to be small. Such evidence is consistent with Borjas and Monras (2016) who do not find any complementarity effects induced by the repatriates on native workers with different skills between 1962-1968. It is also in line with Dustmann et al. (2016b) who find that the wage response to Czech immigration is of similar magnitude whether the immigrant penetration is measured at the local or local-skill levels.

Between 1962 and 1976, the OLS estimated effects of repatriates on wages are insignificant. The IV estimates, however, indicate a significant detrimental impact on the wages of competing natives, implying that the skill group which experienced the greatest

\footnotetext{
${ }^{70}$ In order to have enough observations to compute region-skill specific wages for the first age group in 1976, I do not exclude from the 1977 wage data the pre-existing natives who start their their professional career after 1961. This sample definition allows me to have a full set of observations to implement regressions (i.e., 252 observations) between 1962-1976. Otherwise, I have only 222 observations to run regressions. I also use the sample having 222 observations to investigate the within-skill group impact of the repatriates between 1962-1976 and find similar results than with the full sample of 252 observations. The results are available upon request.
} 
supply shock suffered the largest wage decline. This result suggests that the direct partial impact of immigration on the wages of similarly skilled natives remained 15 years after the independence of Algeria.

Finally, the IV estimated coefficients between 1962-1976 are close to those obtained for the 1962-1968 period. ${ }^{71}$ This result is consistent with the fact that the identifying strategy absorbs all wage effects that are common to all skill groups and, therefore, does not account for the potential positive wage effects induced by capital accumulation in the longer-run.

\section{Employment Effects}

Table 8 studies how the regional penetration of repatriates affected the employment opportunities of pre-existing natives between 1962 and 1968 for the sample of men and the sample of women. ${ }^{72}$ I use two main dependent variables: the employment rate to population and the participation rate. ${ }^{73}$ I compute the dependent variables at the educationregion level and add education fixed effects as covariates to control for unobserved demand shocks at the education level. ${ }^{74}$ I also include the same index of sector-specific growth as the one discussed in Section 5.1 to control for regional labor demand shocks.

Table 8 reports OLS and IV estimations where I use rainfall intensity as the baseline instrument. As earlier, I cluster the standard errors at the regional level and weight each re-

\footnotetext{
${ }^{71}$ In Appendix-Table 14, I follow Clemens and Hunt (2017)'s suggestion and show that my baseline results are fully robust to the specification correction proposed by Kronmal (1993). More specifically, I decompose $\triangle m_{i j r}$ into the log number of repatriates and the log number of pre-existing natives. As instrument for the log number of repatriates, I use the log predicted number of repatriates based on Equation 17. I implement regressions for the baseline sample and the alternative sample defining skill groups at the education-age level. The sign, significance and magnitude of the estimated wage effects induced by the repatriates are similar to the baseline results reported in Table 7.

${ }^{72}$ Because the structure of the 1975 census does not allow me to disentangle the repatriates from preexisting natives, it is not possible to analyze the employment dynamics induced by the repatriate supply shock.

${ }^{73}$ Appendix-Table 13 reports the changes in employment rate to population and in participation rate for the samples of pre-existing native men and women between 1962-1968.

${ }^{74}$ It is impossible to compute the dependent variables at the education-occupation-region level since unemployed and inactive natives cannot be assigned to a particular occupation. Note that Card (2001); Angrist and Kugler (2003); Smith (2012); Edo (2015); Edo and Rapoport (2017) also use employment rates to study the impact of immigration on native employment opportunities.
} 
gression by $\left(n_{i r}^{1968} n_{i r}^{1962}\right) /\left(n_{i r}^{1968}+n_{i r}^{1962}\right)$, where $n_{i r}^{1968}$ and $n_{i r}^{1962}$ represent the number of preexisting native workers used to compute the dependent variables in each region-education cell in 1968 and 1962, respectively.

Specification 1 uses the baseline measure of regional supply shocks $\Delta m_{r}$ (as in Equation 10), while specification 2 uses $\Delta m_{r}^{1962}$ as an alternative regressor of interest. I find that the inflow of male repatriates decreased the employment rate of male and female native workers. This result is consistent with economic theory: at lower wages, the number of native workers decline. This negative employment response is consistent with Hunt (1992); Clemens and Hunt (2017) who find that a 1 percentage point increase in the repatriate share of the labor force raised the unemployment rate of natives by 0.2 percentage points.

In Table 8, the IV estimated coefficients imply that a 1 percent increase in the size of the region due to an influx of repatriates reduced the employment rate to population by 0.35 percentage points for the sample of men and 1.16 percentage points for the sample of women. This asymmetric employment reaction by gender indicates a stronger displacement effects among women than among men. Such result is consistent with the fact that women's labor supply is generally more responsive to wage changes than men's labor supply (Blau and Kahn, 2007; Evers et al., 2008).

These employment responses could either be driven by a decline in employment rate to labor force or in participation rate, or both. The results on the participation rate suggest that the displaced native men move to both unemployment and inactivity while the displaced native women mostly move to inactivity.

The bottom part of Table 8 implements two subsample regressions to decompose the total employment effects by education group. Specifications 3 and 4 deal respectively with 21 observations ( 1 education group and 21 regions) and 63 observations ( 3 education groups and 21 regions). I find that the regional penetration of repatriates did not affect the employment opportunities of high educated native workers. The detrimental effects on the employment opportunities of pre-existing natives are driven by the sample of natives with less than a high education level. This differentiated effect by education group suggests that the labor supply elasticity is weaker among high educated workers than among low educated ones. 


\section{Conclusion}

This paper exploits the sudden and unexpected massive influx of repatriates from Algeria to France in 1962 to investigate the wage dynamics of labor supply shocks. As documented by the literature (e.g., Hunt, 1992; Friedberg and Hunt, 1995; Okkerse, 2008; Borjas and Monras, 2016), this natural experiment provides an excellent framework to identify causal effects by combining the exogenous push factor of the Algerian independence war with an IV strategy to account for the endogenous allocation of repatriates. I use three alternative instruments to predict repatriate penetration at the regional level: rainfall intensity, distance from Algiers and past immigrant settlement patterns.

The empirical estimates indicate that the influx of repatriates decreased the average wage of pre-existing native workers at the regional level over the 1962-1968 period. This short-run impact is consistent with standard economic theory which predicts that an increase in labor supply induces an immediate negative wage response. Over the 19681976 period, however, I find that the influx of repatriates exerted upward pressure on the regional wage of pre-existing native workers. Because this positive impact fully offsets the negative impact, I conclude that regional wages recovered after about 15 years.

The wage dynamic identified in this paper is consistent with standard economic theory which predicts that the average wage has to return to its pre-immigration level in the longrun (Ottaviano and Peri, 2012; Borjas, 2013). This dynamic is also in line with Blanchard et al. (1992); Amior and Manning (2015); Monras (2015b) and Borjas (2016); Monras (2015a); Ruist et al. (2017) who respectively find that the recovery of local-level wages after a negative demand shock or a positive supply shock generally takes more than a decade.

This paper also investigates the distributional consequences induced by the influx of repatriates across skill groups. Although regional wages recovered after 15 years, I find persistent distributional wage effects. In particular, the skill groups which received the most repatriates were the ones where wages grew the least (or fell the most). Because the repatriates disproportionately increased the supply of high-educated workers, they contributed to the reduction of wage inequality between high and low educated native workers over the whole period considered (1962-1976). These results are consistent with standard economic theory which predicts that the distributional effects of immigra- 
tion across skill groups are permanent.

Because repatriate and pre-existing native workers were very close substitutes, the exodus to France at the end of the Algerian war provides a unique opportunity to understand how labor markets respond to supply shocks. However, it is important to notice that the conclusions derived from this case study may not be generalized to other migration contexts where immigrants and natives of similar observable skills (i.e., education and age) are imperfect substitutes or complements in production (Manacorda et al., 2012; Ottaviano and Peri, 2012; Cattaneo et al., 2013; Foged and Peri, 2016). 


\section{References}

AltonJI, J. G. AND D. CARD, "The effects of immigration on the labor market outcomes of less-skilled natives," in Immigration, trade and the labor market (University of Chicago Press, 1991), 201-234.

Amior, M. AND A. MANNING, "The persistence of local joblessness," CEP Discussion Paper No 1357 (2015).

ANGRIST, J. D. AND A. D. KUGLER, "Protective or counter-productive? labour market institutions and the effect of immigration on EU natives," The Economic Journal 113 (2003), F302-F331.

ANGRIST, J. D. AND J.-S. PISCHKE, Mostly harmless econometrics: An empiricist's companion (Princeton university press, 2008).

AYdemiR, A. AND G. J. BORJAS, "Cross-country variation in the impact of international migration: Canada, Mexico, and the United States," Journal of the European Economic Association 5 (2007), 663-708.

—, "Attenuation Bias in Measuring the Wage Impact of Immigration," Journal of Labor Economics 29 (2011), 69-112.

BAILlET, P., "Une population urbanisée: les rapatriés d'Algérie," Bulletin de l'Association de géographes français 52 (1975), 269-278.

BARTIK, T. J., Who benefits from state and local economic development policies? (WE Upjohn Institute for Employment Research, 1991).

BAsso, G. AND G. PeRI, "The Association between Immigration and Labor Market Outcomes in the United States," IZA DP No. 9436 (2015).

Blanchard, O. J., L. F. Katz, R. E. Hall and B. Eichengreen, "Regional evolutions," Brookings papers on economic activity 1992 (1992), 1-75.

BLAU, F. D. AND L. M. KAHN, "The gender pay gap," The Economists' Voice 4 (2007). 
BORJAS, G. J., "Immigrants, Minorities, and Labor Market Competition," Industrial and Labor Relations Review 40 (1987), 382-392.

gration on the labor market," The quarterly journal of economics 118 (2003), 1335-1374.

— , "Native internal migration and the labor market impact of immigration," Journal of Human Resources 41 (2006), 221-258.

_- "The analytics of the wage effect of immigration," IZA Journal of Migration 2 (2013), 22.

—. Immigration Economics (Harvard University Press, 2014).

_-, "The Wage Impact of the Marielitos: A Reappraisal," Industrial and Labor Relations Review (September 2016).

Borjas, G. J., R. B. Freeman and L. F. Katz, "How much do immigration and trade affect labor market outcomes?," Brookings papers on economic activity 1997 (1997), $1-90$.

BorJas, G. J., J. Grogger and G. H. HANSON, "Comment: On Estimating Elasticities Of Substition," Journal of the European Economic Association 10 (2012), 198-210.

BorJas, G. J. AND J. MONRAS, "The Labor Market Consequences of Refugee Supply Shocks," Economic Policy (Forthcoming) (2016).

Boustan, L. P., P. V. Fishback And S. KantoR, "The effect of internal migration on local labor markets: American cities during the Great Depression," Journal of Labor Economics 28 (2010), 719-746.

Bratsberg, B. AND O. RaAum, "Immigration and Wages: Evidence from Construction*," The Economic Journal 122 (2012), 1177-1205.

Braun, S. AND H. WeBer, "How do regional labor markets adjust to immigration? A dynamic analysis for post-war Germany," Kiel Working Paper No. 2025 (2016). 
BrückeR, H., A. Hauptmann, E. J. Jahn and R. Upward, "Migration and imperfect labor markets: Theory and cross-country evidence from Denmark, Germany and the UK," European Economic Review 66 (2014), 205-225.

Cameron, A. C., J. B. Gelbach and D. L. Miller, "Bootstrap-based improvements for inference with clustered errors," The Review of Economics and Statistics 90 (2008), 414-427.

CARD, D., "The Impact of the Mariel Boatlift on the Miami Labor Market," Industrial and Labor Relations Review 43 (1990), 245-257.

_- "Immigrant Inflows, Native Outflows, and the Local Labor Market Impacts of Higher Immigration," Journal of Labor Economics 19 (2001), 22-64.

—_, "How Immigration Affects US Cities," CReAM Discussion Paper No. 11/07 (2007).

Cattaneo, C., C. V. Fiorio AND G. Peri, "Immigration and careers of European workers: effects and the role of policies," IZA Journal of European Labor Studies 2 (2013), 17.

Clemens, M. A. AND J. Hunt, "The Labor Market Effects of Refugee Waves: Reconciling Conflicting Results,” NBER No. 23433 (May 2017).

Cohen-Goldner, S. And M. D. Paserman, "The dynamic impact of immigration on natives' labor market outcomes: Evidence from Israel," European Economic Review 55 (2011), 1027-1045.

COLAS, M., "Dynamic responses to immigration," Mimeo (2016).

Conley, T. G., C. B. Hansen And P. E. Rossı, "Plausibly exogenous," Review of Economics and Statistics 94 (2012), 260-272.

CORTES, P., "The effect of low-skilled immigration on US prices: evidence from CPI data," Journal of political Economy 116 (2008), 381-422.

DAVIDSON, R. AND J. G. MACKInNON, "Wild bootstrap tests for IV regression," Journal of Business \& Economic Statistics 28 (2010), 128-144. 
Docquier, F., Ç. Ozden AND G. PeRI, "The labour market effects of immigration and emigration in OECD countries," The Economic Journal 124 (2014), 1106-1145.

Dustmann, C., F. Fabbri and I. Preston, "The Impact of Immigration on the British Labour Market*," The Economic Journal 115 (2005), F324-F341.

Dustmann, C., T. Frattini And I. P. Preston, "The effect of immigration along the distribution of wages," The Review of Economic Studies 80 (2013), 145-173.

Dustmann, C. ANd A. GlitZ, "How do industries and firms respond to changes in local labor supply?," Journal of Labor Economics 33 (2015), 711-750.

Dustmann, C., U. Schönberg and J. Stuhler, "The impact of immigration: Why do studies reach such different results?", The Journal of Economic Perspectives 30 (2016a), 31-56.

— - "Labor supply shocks, native wages, and the adjustment of local employment," The Quarterly Journal of Economics (2016b), qjw032.

Edo, A., "The impact of immigration on native wages and employment," The BE Journal of Economic Analysis \& Policy 15 (2015), 1151-1196.

- "How do rigid labor markets absorb immigration? Evidence from France," IZA Journal of Migration 5 (2016), 1-20.

Edo, A. AND H. RAPOPORT, "Minimum Wages and the Labor Market Effects of Immigration," CEPII WP No. 2017-12 (2017).

Edo, A. And F. Toubal, "Selective Immigration Policies and Wages Inequality," Review of International Economics 23 (2015), 160-187.

_- "Immigration and the gender wage gap," European Economic Review 92 (2017), 196-214.

Evers, M., R. De Moolj and D. Van Vuuren, "The wage elasticity of labour supply: a synthesis of empirical estimates," De Economist 156 (2008), 25-43. 
Foged, M. AND G. PERI, 'Immigrants' effect on native workers: New analysis on longitudinal data," American Economic Journal: Applied Economics 8 (2016), 1-34.

Friedberg, R. M., "The impact of mass migration on the Israeli labor market," The Quarterly Journal of Economics 116 (2001), 1373-1408.

Friedberg, R. M. AND J. Hunt, "The impact of immigrants on host country wages, employment and growth," The Journal of Economic Perspectives 9 (1995), 23-44.

GolDIN, C., "The political economy of immigration restriction in the United States, 1890 to 1921," in The regulated economy: A historical approach to political economy (University of Chicago Press, 1994), 223-258.

GolLIN, D., "Getting income shares right," Journal of political Economy 110 (2002), 458474.

Greenaway-McGrevy, R. AND K. HoOd, "Aggregate effects and measuring regional dynamics," Bureau of Economic Analysis, Washington, DC (2011).

HAMERMESH, D. S., Labor demand (princeton University press, 1993).

HANSON, G. H., "The economic consequences of the international migration of labor," Annu. Rev. Econ. 1 (2009), 179-208.

HUNT, J., "The impact of the 1962 repatriates from Algeria on the French labor market," Industrial and Labor Relations Review (1992), 556-572.

_- "The impact of immigration on the educational attainment of natives," Journal of Human Resources (2016), 0115-6913R1.

JONES, C. I., "The shape of production functions and the direction of technical change," The Quarterly Journal of Economics 120 (2005), 517-549.

Kronmal, R. A., "Spurious correlation and the fallacy of the ratio standard revisited," Journal of the Royal Statistical Society. Series A (Statistics in Society) (1993), 379-392. 
KUGLER, A. AND M. YUKSEL, "Effects of low-skilled immigration on US natives: evidence from Hurricane Mitch," NBER No. 14293 (2008).

Lebourgeois, F., A. Granier and N. Bréda, "Une analyse des changements climatiques régionaux en France entre 1956 et 1997. Réflexions en terme de conséquences pour les écosystèmes forestiers," Annals of forest science 58 (2001), 733-754.

LEWIS, E., "Immigration, skill mix, and capital skill complementarity," The Quarterly Journal of Economics 126 (2011), 1029-1069.

__, "Immigration and Production Technology," Annu. Rev. Econ. 5 (2013), 165-191.

LeWIS, E. AND G. PerI, "Immigration and the Economy of Cities and Regions," Handbook of Regional and Urban Economics 5 (2015), 625-685.

Lichter, A., A. Peichl and S. Siegloch, "The own-wage elasticity of labor demand: A meta-regression analysis," European Economic Review 80 (2015), 94-119.

LLULL, J., "The effect of immigration on wages: exploiting exogenous variation at the national level," Journal of Human Resources (2017), 0315-7032R2.

Manacorda, M., A. Manning And J. Wadsworth, "The Impact of Immigration on the Structure of Wages: Theory and Evidence from Britain," Journal of the European Economic Association (2012).

McDonald, J. R., "The Repatriation of French Algerians 1962-1963," International Migration 3 (1965), 146-157.

Molloy, R., C. L. Smith and A. Wozniak, "Internal migration in the United States," The Journal of Economic Perspectives 25 (2011), 173-196.

MONFORT, M., "'Lévolution de la structure éducative de la population active française entre 1962 et 1968," Revue française de pédagogie (1972), 19-39.

MONRAS, J., "Immigration and wage dynamics: Evidence from the mexican peso crisis," IZA DP No. 8924 (2015a). 
- "Minimum Wages and Spatial Equilibrium: Theory and Evidence," IZA DP No. $9460(2015 b)$.

MOULTON, B. R., "An illustration of a pitfall in estimating the effects of aggregate variables on micro units," The review of Economics and Statistics (1990), 334-338.

Moumen, A., "De l'Algérie à la France. Les conditions de départ et d'accueil des rapatriés, pieds-noirs et harkis en 1962," Matériaux pour l'histoire de notre temps (2010), 60-68.

OKKERSE, L., "How to measure labour market effects of immigration: A review," Journal of Economic Surveys 22 (2008), 1-30.

Ortega, J. And G. Verdugo, "Moving up or down? Immigration and the selection of natives across occupations and locations," Mimeo (2017).

Ottaviano, G. I. AND G. Peri, "Immigration and national wages: Clarifying the theory and the empirics," NBER No. 14188 (2008).

_ nomic Association 10 (2012), 152-197.

PekKala KerR, S. AND W. KerR, "Economic Impacts of Immigration: A Survey," Finnish Economic Papers 24 (2011), 1-32.

PERI, G., "The effect of immigration on productivity: Evidence from US states," Review of Economics and Statistics 94 (2012), 348-358.

_ , "Immigrants, Productivity, and Labor Markets," The Journal of Economic Perspectives 30 (2016), 3-29.

Peri, G., K. ShIH AND C. SPARBER, "STEM workers, H-1B visas, and productivity in US cities," Journal of Labor Economics 33 (2015), S225-S255.

Peri, G. ANd C. SPARBer, "Task specialization, immigration, and wages," American Economic Journal: Applied Economics (2009), 135-169. 
— , "Assessing inherent model bias: An application to native displacement in response to immigration," Journal of Urban Economics 69 (2011a), 82-91.

—- "Highly Educated Immigrants and Native Occupational Choice," Industrial Relations: A Journal of Economy and Society 50 (2011b), 385-411.

Peri, G. AND V. YASENOV, "The Labor Market Effects of a Refugee Wave: Applying the Synthetic Control Method to the Mariel Boatlift," NBER No. 21801 (2015).

RUIST, J., J. STUHLER AND D. A. JAEGER, "Shift-Share Instruments and the Impact of Immigration," Mimeo (2017).

RYBCZYNSKI, T. M., "Factor endowment and relative commodity prices," Economica 22 (1955), 336-341.

SÁ, F., "Immigration and House Prices in the UK," The Economic Journal 125 (2015), 1393-1424.

SMITH, C. L., "The impact of low-skilled immigration on the youth labor market," Journal of Labor Economics 30 (2012), 55-89.

SOLON, G., S. J. HAIDER AND J. M. WOOLDRIDGE, "What are we weighting for?," Journal of Human resources 50 (2015), 301-316.

StOck, J. H., J. H. WRIGHT AND M. YOGO, "A survey of weak instruments and weak identification in generalized method of moments," Journal of Business \& Economic Statistics 20 (2002).

Tumen, S., "The Economic Impact of Syrian Refugees on Host Countries: QuasiExperimental Evidence from Turkey," The American Economic Review 106 (2016), 456460.

WOZNIAK, A. AND T. J. MURRAY, "Timing is everything: Short-run population impacts of immigration in US cities," Journal of Urban Economics 72 (2012), 60-78. 
ZYTNICKI, C., "L'administration face à l'arrivée des rapatriés d'Algérie: l'exemple de la région Midi-Pyrénées," Annales du Midi: revue archéologique, historique et philologique de la France méridionale 110 (1998), 501-521. 


\section{Figures}

Figure 1: Number of repatriates from Algeria to France between 1962 and 1968

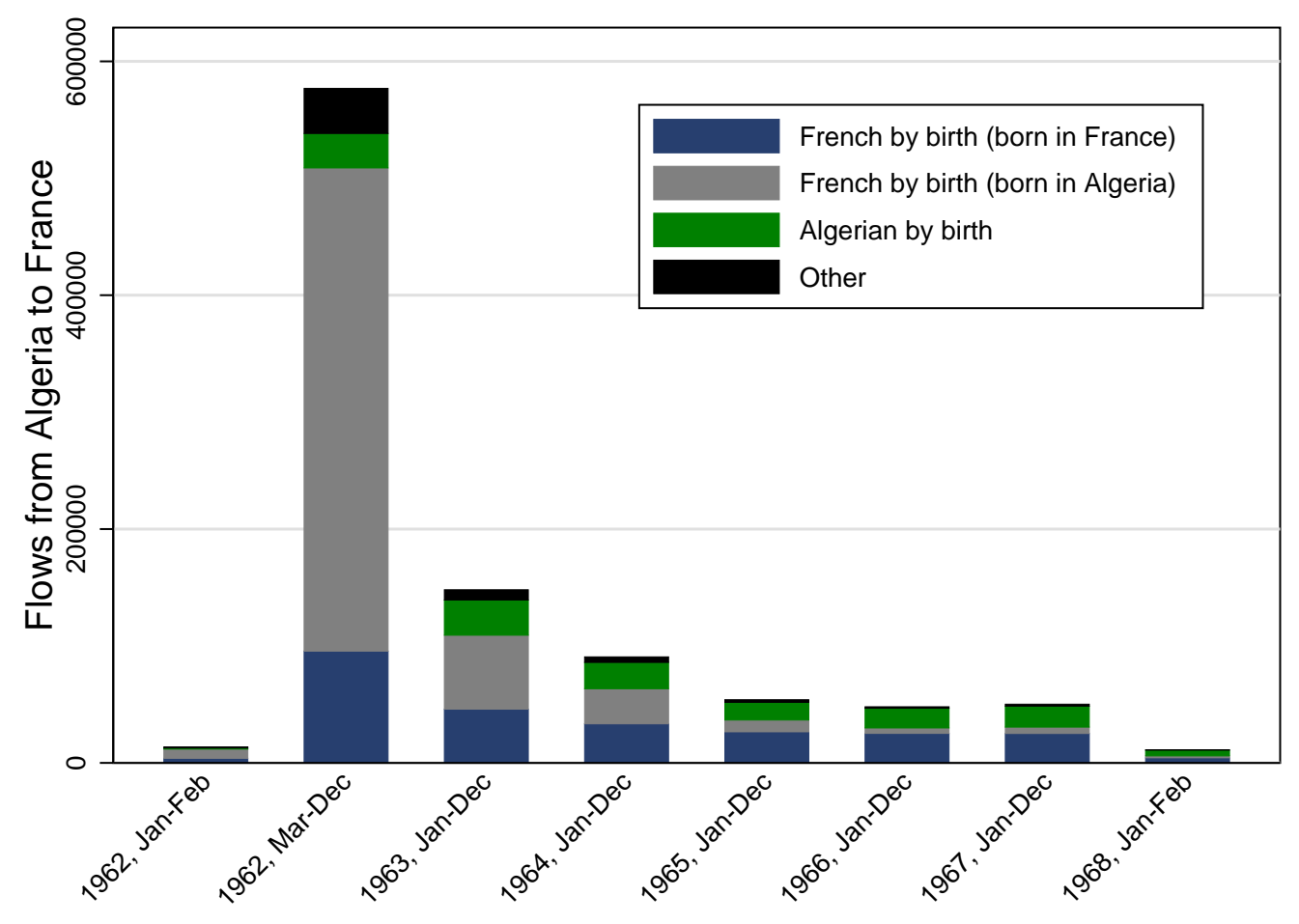

Notes. The population used includes all men and women who were in Algeria the first January 1962 and arrived in France until February 1968. 
Figure 2: Percent supply shifts induced by the inflow of repatriates across regions

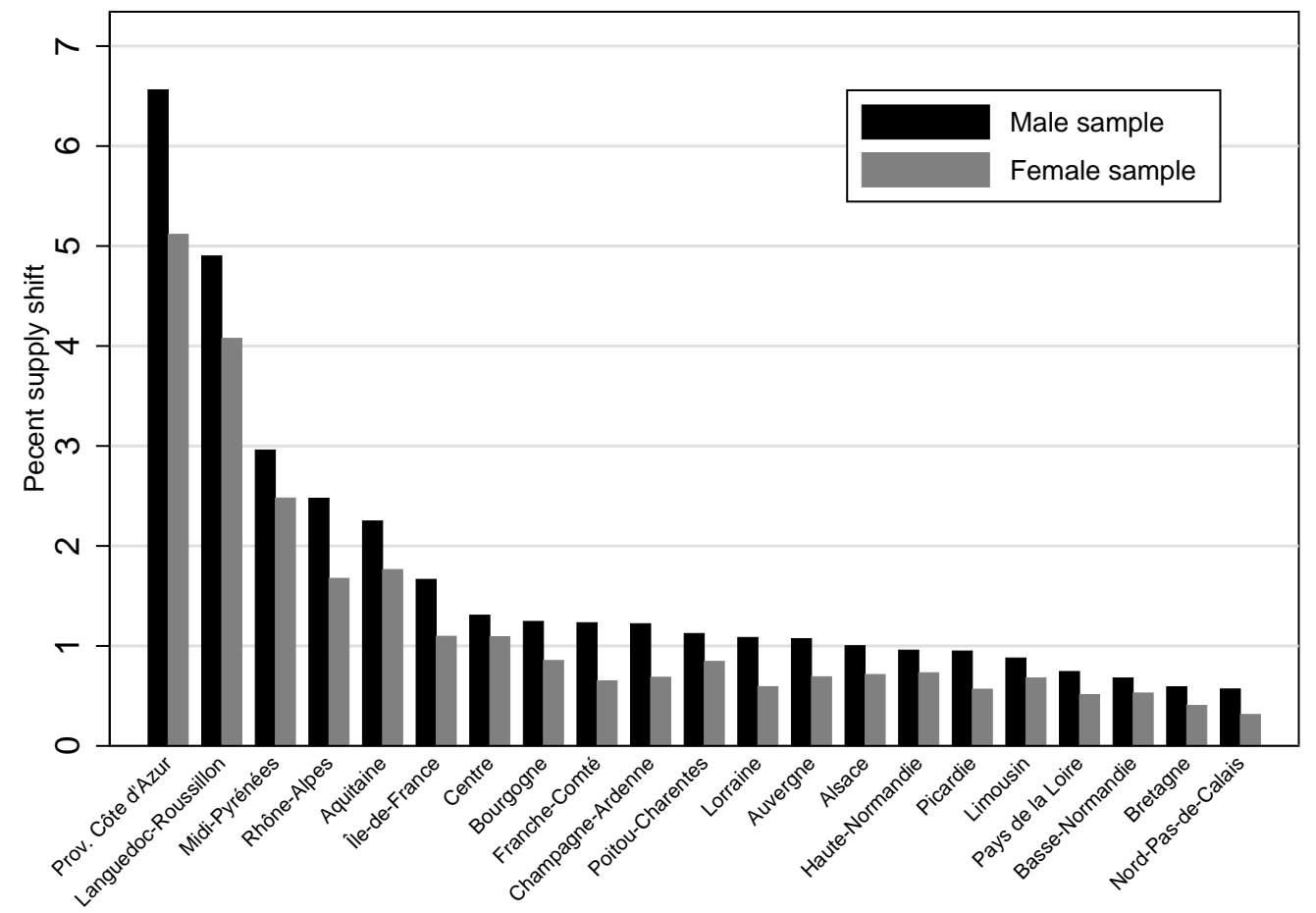

Notes. The population used includes men and women in the labor force, aged from 18 to 64 , not enrolled at school and not selfemployed. Each bar presents the percentage of 1962 repatriates relative to the pre-existing native workers for the samples of men and women. Corsica is not included in the sample. 
Figure 3: Relation between wages and repatriates at the region-educationoccupation level, 1962-1968

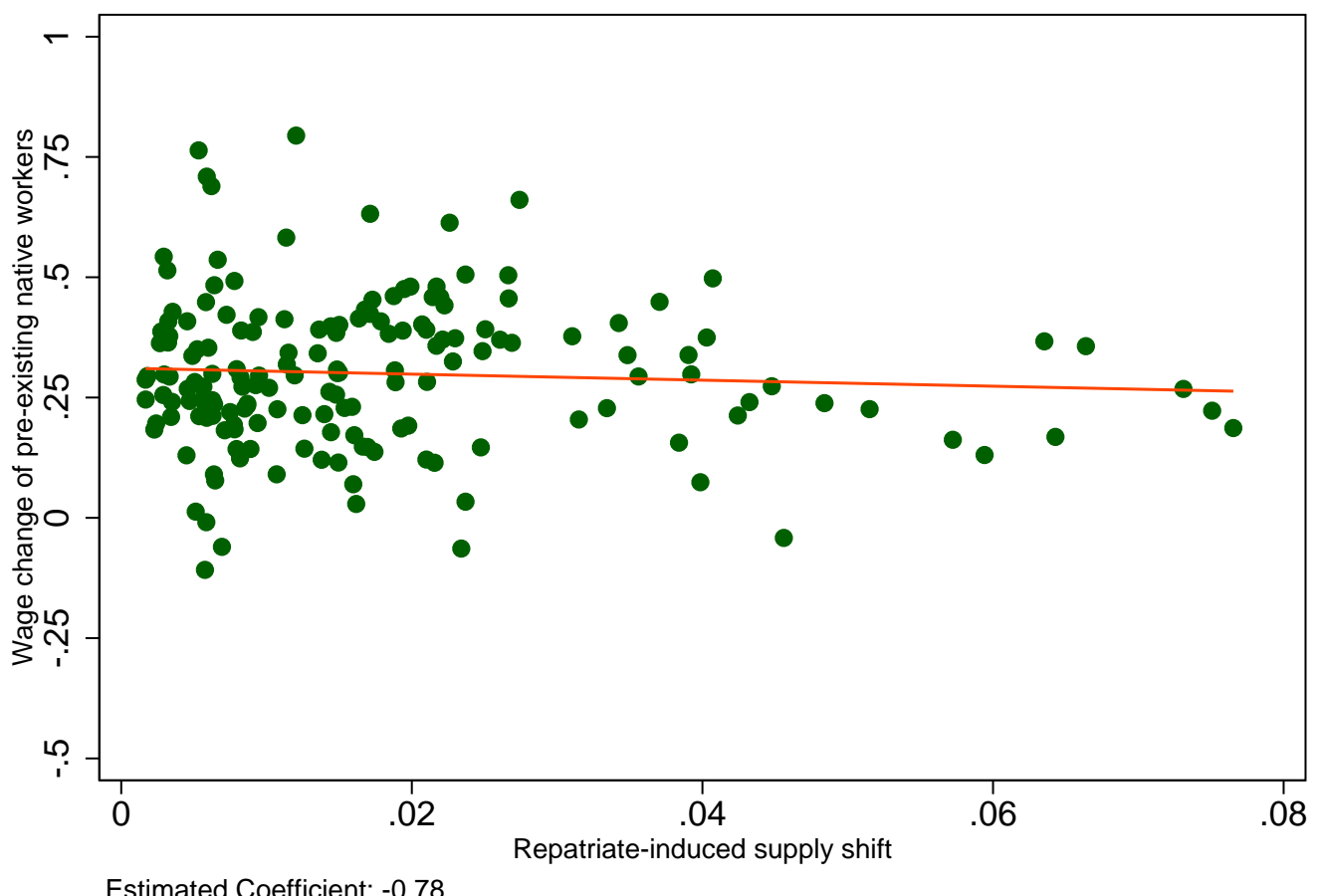

Student's t-test: -1.72

Notes. Each point in the scatter represents the change in the log wage of male pre-existing native workers and the density of repatriates for a region-skill group. I divide skill groups into 4 education groups and 2 occupation groups. The regression line in the figure weighs the data by $\left(n^{0} n^{1}\right) /\left(n^{0}+n^{1}\right)$, where $n^{0}$ and $n^{1}$ represent the number of pre-existing native workers used to compute the dependent variables in each region-skill cell in 1962 and 1968, respectively. 
Figure 4: Relation between wages and repatriates at the region-education-age level, 1962-1968

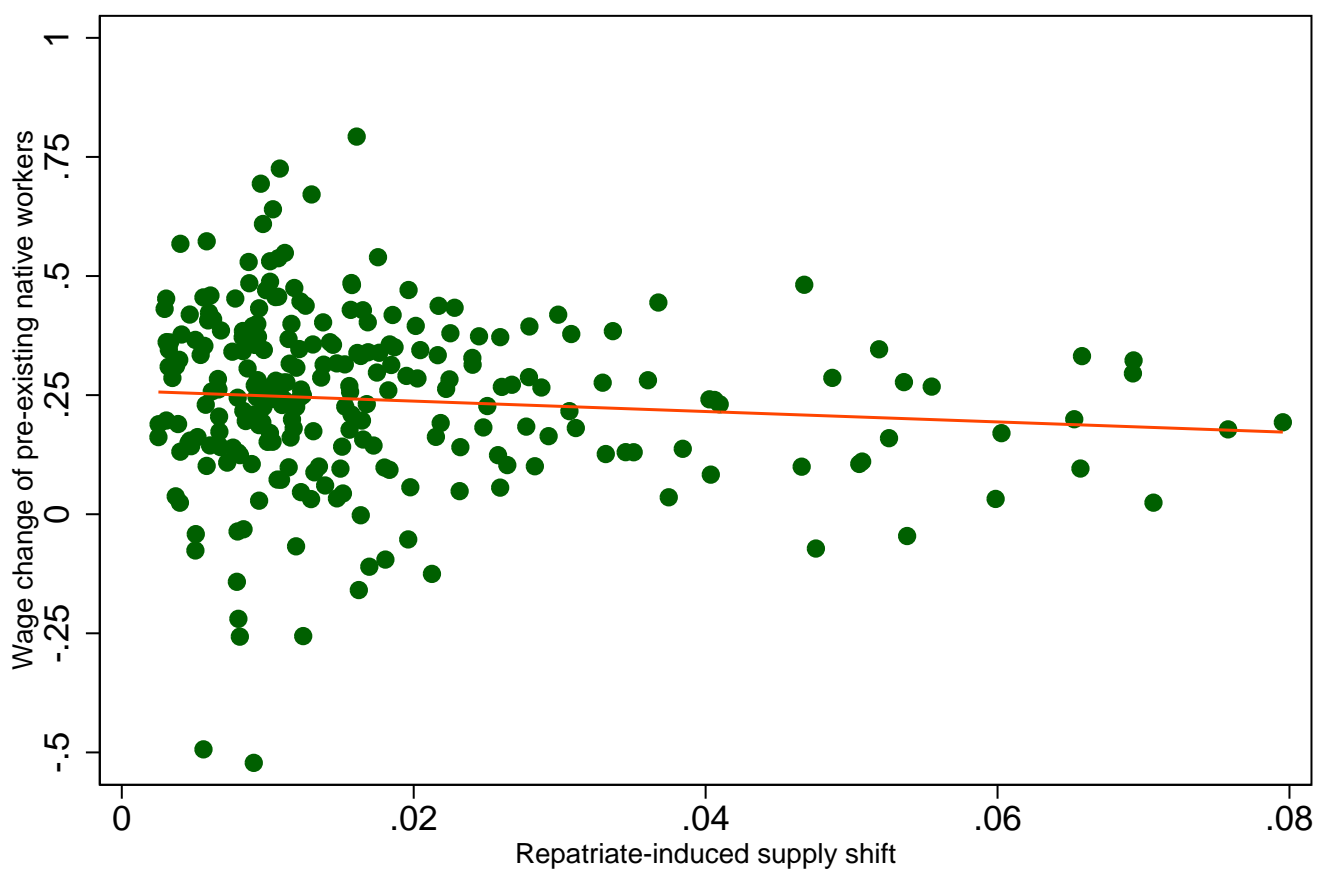

Estimated Coefficient: -1.10 Student's t-test: -2.29

Notes. Each point in the scatter represents the change in the log wage of male pre-existing native workers and the density of repatriates for a region-skill group. I divide skill groups into 4 education groups and 3 age groups. The regression line in the figure weighs the data by $\left(n^{0} n^{1}\right) /\left(n^{0}+n^{1}\right)$, where $n^{0}$ and $n^{1}$ represent the number of pre-existing native workers used to compute the dependent variables in each region-skill cell in 1962 and 1968, respectively. 


\section{Tables - Descriptive Statistics}

Table 1: Sample size of pre-existing native workers across regions

\begin{tabular}{|c|c|c|c|c|c|c|c|}
\hline \multirow[b]{2}{*}{ Rank } & \multirow[b]{2}{*}{ French region } & \multicolumn{2}{|c|}{1962} & \multicolumn{2}{|c|}{1969} & \multicolumn{2}{|c|}{1976} \\
\hline & & Men & Women & Men & Women & Men & Women \\
\hline 1 & Prov. Côte d'Azur & 582 & 223 & 683 & 215 & 423 & 180 \\
\hline 2 & Languedoc-Roussillon & 246 & 78 & 287 & 63 & 184 & 66 \\
\hline 3 & Midi-Pyrénées & 318 & 145 & 406 & 118 & 283 & 117 \\
\hline 4 & Rhône-Alpes & 758 & 357 & 1,021 & 281 & 688 & 319 \\
\hline 5 & Aquitaine & 377 & 163 & 457 & 121 & 371 & 159 \\
\hline 6 & Île-de-France & 2,456 & 1,146 & 2,873 & 1,065 & 1,554 & 972 \\
\hline 7 & Centre & 331 & 124 & 425 & 150 & 319 & 147 \\
\hline 8 & Bourgogne & 224 & 93 & 376 & 97 & 202 & 73 \\
\hline 9 & Franche-Comté & 179 & 70 & 215 & 61 & 164 & 77 \\
\hline 10 & Champagne-Ardenne & 210 & 101 & 289 & 94 & 219 & 81 \\
\hline 11 & Poitou-Charentes & 231 & 108 & 284 & 82 & 206 & 87 \\
\hline 12 & Lorraine & 408 & 147 & 583 & 123 & 312 & 104 \\
\hline 13 & Auvergne & 168 & 72 & 258 & 84 & 195 & 69 \\
\hline 14 & Alsace & 253 & 82 & 442 & 104 & 263 & 105 \\
\hline 15 & Haute-Normandie & 244 & 138 & 435 & 113 & 324 & 126 \\
\hline 16 & Picardie & 234 & 103 & 317 & 79 & 247 & 79 \\
\hline 17 & Limousin & 108 & 48 & 190 & 61 & 93 & 49 \\
\hline 18 & Pays de la Loire & 339 & 154 & 597 & 165 & 456 & 175 \\
\hline 19 & Basse-Normandie & 175 & 88 & 273 & 80 & 197 & 98 \\
\hline 20 & Bretagne & 330 & 141 & 506 & 108 & 377 & 161 \\
\hline 21 & Nord-Pas-de-Calais & 510 & 223 & 955 & 199 & 593 & 185 \\
\hline Total & & 8,681 & 3,804 & 11,872 & 3,463 & 7,670 & 3,429 \\
\hline
\end{tabular}

Notes. The population used includes pre-existing native workers aged from 18 to 64 , not enrolled at school and not self-employed. Corsica is not included in the sample. 
Table 2: The size of the supply shock induced by the repatriates

\begin{tabular}{|c|c|c|c|c|c|c|c|c|}
\hline & \multicolumn{4}{|c|}{ Sample of men } & \multicolumn{4}{|c|}{ Sample of women } \\
\hline & $\begin{array}{c}\text { Pre-existing } \\
\text { natives }\end{array}$ & Repatriates & $\begin{array}{l}\text { Density } \\
\text { of repat. }\end{array}$ & $\begin{array}{c}\text { Percent } \\
\text { supply shift }\end{array}$ & $\begin{array}{c}\text { Pre-existing } \\
\text { natives }\end{array}$ & Repatriates & $\begin{array}{l}\text { Density } \\
\text { of repat. }\end{array}$ & $\begin{array}{c}\text { Percent } \\
\text { supply shift }\end{array}$ \\
\hline \multicolumn{9}{|l|}{ Education } \\
\hline High & 14.1 & 17.9 & 1.3 & 2.3 & 15.1 & 20.1 & 1.3 & 1.7 \\
\hline Medium & 22.4 & 21.3 & 1.0 & 1.7 & 26.3 & 31.8 & 1.2 & 1.6 \\
\hline Low & 30.8 & 29.7 & 1.0 & 1.7 & 30.8 & 24.7 & 0.8 & 1.0 \\
\hline Very low & 32.7 & 31.2 & 1.0 & 1.7 & 27.8 & 23.4 & 0.8 & 1.1 \\
\hline \multicolumn{9}{|l|}{ Age } \\
\hline$[18 ; 30]$ & 32.9 & 29.8 & 0.9 & 1.6 & 43.2 & 45.1 & 1.0 & 1.3 \\
\hline ]30;44] & 36.3 & 42.3 & 1.2 & 2.1 & 27.7 & 31.0 & 1.1 & 1.4 \\
\hline ]44;64] & 30.8 & 27.9 & 0.9 & 1.6 & 29.1 & 23.9 & 0.8 & 1.1 \\
\hline \multicolumn{9}{|l|}{ Occupation } \\
\hline Service & 43.9 & 64.8 & 1.5 & 2.6 & 67.5 & 81.2 & 1.2 & 1.5 \\
\hline Non-service & 56.1 & 35.2 & 0.6 & 1.1 & 32.5 & 18.8 & 0.6 & 0.7 \\
\hline
\end{tabular}

Notes. The population used includes men and women in the labor force aged from 18 to 64, not enrolled at school and not selfemployed. Corsica is not included in the sample. 


\section{Tables - Empirical Results}


Table 3: The impact of repatriates on native wages

\begin{tabular}{|c|c|c|c|c|c|c|}
\hline & \multicolumn{6}{|c|}{ Change in native wages between } \\
\hline & \multicolumn{2}{|c|}{$1962-1968$} & \multicolumn{2}{|c|}{ 1968-1976 } & \multicolumn{2}{|c|}{$1962-1976$} \\
\hline & Baseline & $\begin{array}{l}\text { Additional } \\
\text { controls }\end{array}$ & Baseline & $\begin{array}{l}\text { Additional } \\
\text { controls }\end{array}$ & Baseline & $\begin{array}{c}\text { Additional } \\
\text { controls }\end{array}$ \\
\hline 1. OLS estimate & $\begin{array}{l}-1.29^{* * *} \\
(-3.13)\end{array}$ & $\begin{array}{l}-1.34^{* *} \\
(-2.71)\end{array}$ & $\begin{array}{l}0.86^{* *} \\
(2.34)\end{array}$ & $\begin{array}{l}1.40^{* * *} \\
(4.43)\end{array}$ & $\begin{array}{l}-0.40 \\
(-0.90)\end{array}$ & $\begin{array}{l}-0.01 \\
(-0.02)\end{array}$ \\
\hline $\begin{array}{l}\text { 2. IV estimate using } \\
\text { rainfall as instrument }\end{array}$ & $\begin{array}{l}-1.91^{\star *} \\
(-2.56)\end{array}$ & $\begin{array}{l}-2.07^{\star *} \\
(-2.51)\end{array}$ & $\begin{array}{l}0.96^{\star *} \\
(2.16)\end{array}$ & $\begin{array}{l}1.72^{\star * *} \\
(4.30)\end{array}$ & $\begin{array}{l}-0.97 \\
(-1.45)\end{array}$ & $\begin{array}{c}-0.72 \\
(-0.60)\end{array}$ \\
\hline F-stat of instrument & 86.76 & 63.36 & 79.32 & 59.09 & 79.78 & 45.18 \\
\hline $\begin{array}{l}\text { 3. IV estimate using } \\
\text { distance as instrument }\end{array}$ & $\begin{array}{l}-1.21^{*} \\
(-1.68)\end{array}$ & $\begin{array}{l}-1.70^{* *} \\
(-2.40)\end{array}$ & $\begin{array}{c}1.37^{*} \\
(1.78)\end{array}$ & $\begin{array}{l}1.59^{* * *} \\
(3.26)\end{array}$ & $\begin{array}{c}0.10 \\
(0.10)\end{array}$ & $\begin{array}{c}0.53 \\
(0.35)\end{array}$ \\
\hline F-stat of instrument & 13.64 & 20.66 & 13.17 & 18.93 & 13.45 & 15.65 \\
\hline $\begin{array}{l}\text { 4. IV estimate using } \\
\text { shift-share instrument }\end{array}$ & $\begin{array}{l}-1.70^{\star \star *} \\
(-2.80)\end{array}$ & $\begin{array}{l}-1.58^{\star \star *} \\
(-2.82)\end{array}$ & $\begin{array}{c}0.23 \\
(0.47)\end{array}$ & $\begin{array}{l}1.05^{\star \star *} \\
(2.65)\end{array}$ & $\begin{array}{l}-1.37 \\
(-1.57)\end{array}$ & $\begin{array}{l}-1.36 \\
(-1.36)\end{array}$ \\
\hline F-stat of instrument & 390.91 & 512.86 & 316.59 & 333.41 & 390.13 & 363.35 \\
\hline Education-sector FE & Yes & Yes & Yes & Yes & Yes & Yes \\
\hline Cluster & 21 & 21 & 21 & 21 & 21 & 21 \\
\hline Observations & 168 & 168 & 168 & 168 & 168 & 168 \\
\hline
\end{tabular}

Key. ${ }^{* * *},{ }^{* *},{ }^{*}$ denote statistical significance from zero at the $1 \%, 5 \%, 10 \%$ significance level. T-statistics are indicated in parentheses below the point estimate.

Notes. The table reports the estimated effects of the 1962 repatriates on the wages of pre-existing native workers for the sample of men only. All regressions have 168 observations (4 education groups, 2 occupations and 21 regions) and include skill fixed effects. Each regression is weighted by using the number of individuals used to compute the dependent variable. Standard errors are adjusted for clustering at the regional level. 
Table 4: The impact of repatriates on native wages using the Kronmal's correction

\begin{tabular}{|c|c|c|c|c|c|c|}
\hline & \multicolumn{6}{|c|}{ Change in native wages between } \\
\hline & \multicolumn{2}{|c|}{ 1962-1968 } & \multicolumn{2}{|c|}{ 1968-1976 } & \multicolumn{2}{|c|}{$1962-1976$} \\
\hline & OLS & IV & OLS & IV & OLS & IV \\
\hline Log of repatriates & $\begin{array}{l}-0.033^{\star *} \\
(-2.71)\end{array}$ & $\begin{array}{c}-0.041^{\star \star \star} \\
(-3.57)\end{array}$ & $\begin{array}{c}0.028^{\star \star \star} \\
(3.00)\end{array}$ & $\begin{array}{c}0.026^{\star \star \star} \\
(2.78)\end{array}$ & $\begin{array}{l}0.005 \\
(0.29)\end{array}$ & $\begin{array}{l}-0.019 \\
(-1.04)\end{array}$ \\
\hline $\begin{array}{l}\text { Log of pre-existing natives } \\
\text { in } 1968\end{array}$ & $\begin{array}{l}0.012 \\
(0.66)\end{array}$ & $\begin{array}{l}0.020 \\
(1.16)\end{array}$ & $\begin{array}{c}-0.046^{* * *} \\
(-3.21)\end{array}$ & $\begin{array}{l}-0.044^{* * *} \\
(-3.01)\end{array}$ & $\begin{array}{l}-0.062^{* * *} \\
(-2.93)\end{array}$ & $\begin{array}{c}-0.036^{\star * \star} \\
(-1.63)\end{array}$ \\
\hline F-stat of instrument & - & 209.51 & - & 137.82 & - & 205.26 \\
\hline Education-sector FE & Yes & Yes & Yes & Yes & Yes & Yes \\
\hline Additional controls & Yes & Yes & Yes & Yes & Yes & Yes \\
\hline Cluster & 21 & 21 & 21 & 21 & 21 & 21 \\
\hline Observations & 168 & 168 & 168 & 168 & 168 & 168 \\
\hline
\end{tabular}

Key. ${ }^{* * *},{ }^{* *},{ }^{*}$ denote statistical significance from zero at the $1 \%, 5 \%, 10 \%$ significance level. T-statistics are indicated in parentheses below the point estimate.

Notes. The table reports the estimated effects of the log number of 1962 repatriates and the log number of pre-existing natives on the wages of pre-existing native workers for the sample of men only. All regressions have 168 observations (4 education groups, 2 occupations and 21 regions). They include skill fixed effects and two additional regressors: a bartik control and the change in native employment. Each regression is weighted by using the number of individuals used to compute the dependent variable. Standard errors are adjusted for clustering at the regional level. 
Table 5: The impact of repatriates on native wages, robustness tests

\begin{tabular}{|c|c|c|c|c|c|c|}
\hline & \multicolumn{2}{|c|}{$1962-1969$} & \multicolumn{2}{|c|}{$1968-1976$} & \multicolumn{2}{|c|}{$1962-1976$} \\
\hline & OLS & IV & OLS & IV & OLS & IV \\
\hline 1. $\triangle m_{r}^{1962}$ instead of $\triangle m_{r}^{1968}$ & $\begin{array}{l}-1.16^{\star * *} \\
(-3.08)\end{array}$ & $\begin{array}{l}-1.75^{\star \star} \\
(-2.55)\end{array}$ & $\begin{array}{l}0.83^{* *} \\
(2.38)\end{array}$ & $\begin{array}{l}0.88^{\star *} \\
(2.16)\end{array}$ & $\begin{array}{l}-0.30 \\
(-0.73)\end{array}$ & $\begin{array}{l}-0.89 \\
(-1.44)\end{array}$ \\
\hline 2. $\mathrm{g} \triangle m_{r}^{1962, \text { all }}$ instead of $\triangle m_{r}^{1968}$ & $\begin{array}{l}-1.41^{* * *} \\
(-2.97)\end{array}$ & $\begin{array}{l}-2.24^{\star * *} \\
(-2.58)\end{array}$ & $\begin{array}{l}1.15^{\star *} \\
(2.35)\end{array}$ & $\begin{array}{l}1.12^{\star *} \\
(2.18)\end{array}$ & $\begin{array}{l}-0.22 \\
(-0.39)\end{array}$ & $\begin{array}{l}-1.14 \\
(-1.45)\end{array}$ \\
\hline $\begin{array}{l}\text { 3. Restrictions to native workers from } \\
\text { the private sector only }\end{array}$ & $\begin{array}{l}-1.32^{* * *} \\
(-2.98)\end{array}$ & $\begin{array}{l}-2.04^{* *} \\
(-2.45)\end{array}$ & $\begin{array}{l}0.86^{* *} \\
(2.49)\end{array}$ & $\begin{array}{l}0.92^{\star *} \\
(2.26)\end{array}$ & $\begin{array}{l}-0.41 \\
(-0.79)\end{array}$ & $\begin{array}{l}-1.16 \\
(-1.38)\end{array}$ \\
\hline $\begin{array}{l}\text { 4. Restrictions to native workers } \\
\text { aged } 25-55 \text { instead of } 18-64\end{array}$ & $\begin{array}{l}-0.93^{* *} \\
(-2.09)\end{array}$ & $\begin{array}{l}-1.58^{* *} \\
(-2.10)\end{array}$ & $\begin{array}{l}0.89^{* *} \\
(2.26)\end{array}$ & $\begin{array}{l}0.92^{* *} \\
(2.09)\end{array}$ & $\begin{array}{l}0.02 \\
(0.04)\end{array}$ & $\begin{array}{l}-0.61 \\
(-0.81)\end{array}$ \\
\hline $\begin{array}{l}\text { 5. Three education groups instead of } \\
\text { four to compute } \triangle \log w_{i j r}\end{array}$ & $\begin{array}{l}-1.24^{\star *} \\
(-2.68)\end{array}$ & $\begin{array}{l}-1.85^{\star *} \\
(-2.34)\end{array}$ & $\begin{array}{c}0.68 \\
(1.69)\end{array}$ & $\begin{array}{l}0.81^{*} \\
(1.70)\end{array}$ & $\begin{array}{l}-0.47 \\
(-0.96)\end{array}$ & $\begin{array}{l}-1.00 \\
(-1.39)\end{array}$ \\
\hline $\begin{array}{l}\text { 6. Six education groups instead of } \\
\text { four to compute } \triangle \log w_{i j r}\end{array}$ & $\begin{array}{l}-1.36^{\star * *} \\
(-3.35)\end{array}$ & $\begin{array}{l}-1.99^{* \star *} \\
(-2.69)\end{array}$ & $\begin{array}{l}0.93^{* * *} \\
(2.99)\end{array}$ & $\begin{array}{l}1.04^{* * *} \\
(2.69)\end{array}$ & $\begin{array}{l}-0.40 \\
(-0.87)\end{array}$ & $\begin{array}{l}-0.99 \\
(-1.34)\end{array}$ \\
\hline $\begin{array}{l}\text { 7. } \triangle \log w_{i r} \text { instead of } \triangle \log w_{i j r} \\
\text { using four education groups }\end{array}$ & $\begin{array}{l}-1.33^{\star * *} \\
(-3.71)\end{array}$ & $\begin{array}{l}-1.86^{\star \star *} \\
(-2.92)\end{array}$ & $\begin{array}{l}0.74^{\star *} \\
(2.13)\end{array}$ & $\begin{array}{l}0.84^{*} \\
(1.94)\end{array}$ & $\begin{array}{l}-0.50 \\
(-1.27)\end{array}$ & $\begin{array}{l}-0.99 \\
(-1.63)\end{array}$ \\
\hline 8. Women only & $\begin{array}{c}-3.38^{* * *} \\
(-3.41)\end{array}$ & $\begin{array}{c}-4.09^{* * *} \\
(-3.55)\end{array}$ & $\begin{array}{c}2.12 \\
(1.48)\end{array}$ & $\begin{array}{l}2.60^{*} \\
(1.69)\end{array}$ & $\begin{array}{l}-1.26 \\
(-1.24)\end{array}$ & $\begin{array}{l}-1.87 \\
(-1.56)\end{array}$ \\
\hline
\end{tabular}

Key. ${ }^{* * *},{ }^{* *},{ }^{*}$ denote statistical significance from zero at the 1\%,5\%,10\% significance level. T-statistics are indicated in parentheses below the point estimate.

Notes. The table reports the estimated effects of the 1962 repatriates on the wages of pre-existing native workers for the sample of men only. I use rainfall intensity across regions as instrument. Specifications 1 to 4 and 8 have 168 observations (4 education groups, 2 occupations and 21 regions) and include skill fixed effects. Specification 5 and 6 include skill fixed effects and respectively have 126 and 252 observations. Specification 7 has 84 observations and include education fixed effects. Each regression is weighted by using the number of individuals used to compute the dependent variable. Standard errors are adjusted for clustering at the regional level. 
Table 6: The impact of repatriates on the relative wage of natives across education groups

\begin{tabular}{|c|c|c|c|c|c|c|c|c|}
\hline & \multicolumn{4}{|c|}{ 1962-1968 } & \multicolumn{4}{|c|}{$1962-1976$} \\
\hline & \multicolumn{2}{|c|}{ Baseline } & \multicolumn{2}{|c|}{$\triangle m_{r}^{1962}$} & \multicolumn{2}{|c|}{ Baseline } & \multicolumn{2}{|c|}{$\triangle m_{r}^{1962}$} \\
\hline & OLS & IV & OLS & IV & OLS & IV & OLS & IV \\
\hline $\begin{array}{l}\text { 1. High vs non-high } \\
\text { education }\end{array}$ & $\begin{array}{l}-3.23^{* * *} \\
(-3.95)\end{array}$ & $\begin{array}{l}-3.06^{* * *} \\
(-6.25)\end{array}$ & $\begin{array}{l}-3.11^{* * *} \\
(-3.85)\end{array}$ & $\begin{array}{l}-2.77^{* * *} \\
(-6.40)\end{array}$ & $\begin{array}{l}-1.05^{\star} \\
(-1.87)\end{array}$ & $\begin{array}{l}-0.99^{* * *} \\
(-2.60)\end{array}$ & $\begin{array}{l}-1.06^{* *} \\
(-2.10)\end{array}$ & $\begin{array}{l}-0.89^{* * *} \\
(-2.62)\end{array}$ \\
\hline $\begin{array}{l}\text { 2. High vs medium } \\
\text { education }\end{array}$ & $\begin{array}{l}-1.93^{\star *} \\
(-2.41)\end{array}$ & $\begin{array}{l}-1.82^{\star \star \star} \\
(-3.78)\end{array}$ & $\begin{array}{l}-1.88^{* *} \\
(-2.23)\end{array}$ & $\begin{array}{l}-1.64^{\star \star \star} \\
(-3.83)\end{array}$ & $\begin{array}{l}-0.55 \\
(-0.61)\end{array}$ & $\begin{array}{l}-0.48 \\
(-0.80)\end{array}$ & $\begin{array}{l}-0.63 \\
(-0.68)\end{array}$ & $\begin{array}{l}-0.44 \\
(-0.80)\end{array}$ \\
\hline $\begin{array}{l}\text { 3. High vs low } \\
\text { education }\end{array}$ & $\begin{array}{l}-1.72^{\star \star \star} \\
(-3.54)\end{array}$ & $\begin{array}{l}-1.65^{\star * *} \\
(-5.03)\end{array}$ & $\begin{array}{l}-1.66^{\star * \star} \\
(-3.79)\end{array}$ & $\begin{array}{l}-1.48^{\star * \star} \\
(-5.10)\end{array}$ & $\begin{array}{l}0.05 \\
(0.11)\end{array}$ & $\begin{array}{l}-0.15 \\
(-0.44)\end{array}$ & $\begin{array}{c}0.07 \\
(0.15)\end{array}$ & $\begin{array}{l}-0.14 \\
(-0.44)\end{array}$ \\
\hline $\begin{array}{l}\text { 4. High vs very low } \\
\text { education }\end{array}$ & $\begin{array}{c}-4.49^{\star * *} \\
(-4.07)\end{array}$ & $\begin{array}{l}-4.54^{\star * *} \\
(-5.26)\end{array}$ & $\begin{array}{l}-4.25^{\star * *} \\
(-4.81)\end{array}$ & $\begin{array}{l}-4.11^{* * *} \\
(-5.30)\end{array}$ & $\begin{array}{l}-1.34^{*} \\
(-1.83)\end{array}$ & $\begin{array}{l}-1.33^{* *} \\
(-2.48)\end{array}$ & $\begin{array}{l}-1.32^{\star *} \\
(-2.18)\end{array}$ & $\begin{array}{l}-1.20^{* *} \\
(-2.49)\end{array}$ \\
\hline
\end{tabular}

Key. ${ }^{* * *},{ }^{* *},{ }^{*}$ denote statistical significance from zero at the $1 \%, 5 \%, 10 \%$ significance level. T-statistics are indicated in parentheses below the point estimate.

Notes. The table reports the estimated effects of the 1962 repatriates on the relative wages of pre-existing native workers by education and sector for the sample of men only. I use rainfall intensity across regions as instrument. Each specification has 42 observations and includes skill fixed effects. Each regression is weighted by using the number of individuals used to compute the dependent variable. Standard errors are adjusted for clustering at the regional level. 
Table 7: The within-cell impact of repatriates on native wages

\begin{tabular}{|c|c|c|c|c|c|c|c|c|}
\hline & \multicolumn{4}{|c|}{$1962-1968$} & \multicolumn{4}{|c|}{$1962-1976$} \\
\hline & \multicolumn{2}{|c|}{ Baseline } & \multicolumn{2}{|c|}{$\triangle m_{r}^{1962}$} & \multicolumn{2}{|c|}{ Baseline } & \multicolumn{2}{|c|}{$\triangle m_{r}^{1962}$} \\
\hline & OLS & IV & OLS & IV & OLS & IV & OLS & IV \\
\hline 1. Baseline sample & $\begin{array}{c}-1.35^{\star \star \star} \\
(-3.37)\end{array}$ & $\begin{array}{l}-0.98^{*} \\
(-1.79)\end{array}$ & $\begin{array}{l}-0.87^{* *} \\
(-2.60)\end{array}$ & $\begin{array}{l}-0.94^{*} \\
(-1.75)\end{array}$ & $\begin{array}{l}-0.52 \\
(-1.06)\end{array}$ & $\begin{array}{l}-1.25^{\star *} \\
(-2.00)\end{array}$ & $\begin{array}{l}-0.16 \\
(-0.36)\end{array}$ & $\begin{array}{l}-1.21^{* *} \\
(-2.02)\end{array}$ \\
\hline F-stat of instrument & - & 87.00 & - & 43.98 & - & 70.89 & - & 39.47 \\
\hline $\begin{array}{l}\text { 2. Six education } \\
\text { groups instead of four }\end{array}$ & $\begin{array}{l}-1.43^{* * *} \\
(-3.27)\end{array}$ & $\begin{array}{l}-1.12^{*} \\
(-1.94)\end{array}$ & $\begin{array}{l}-0.85^{\star *} \\
(-2.16)\end{array}$ & $\begin{array}{l}-1.11^{*} \\
(-1.93)\end{array}$ & $\begin{array}{l}-0.57 \\
(-1.13)\end{array}$ & $\begin{array}{l}-1.02^{*} \\
(-1.68)\end{array}$ & $\begin{array}{l}-0.20 \\
(-0.48)\end{array}$ & $\begin{array}{l}-1.01^{*} \\
(-1.68)\end{array}$ \\
\hline F-stat of instrument & - & 90.62 & - & 50.00 & - & 81.49 & - & 46.84 \\
\hline $\begin{array}{l}\text { 3. Region-education } \\
\text { groups }\end{array}$ & $\begin{array}{l}-1.44^{* * *} \\
(-3.24)\end{array}$ & $\begin{array}{l}-1.70^{\star \star *} \\
(-2.88)\end{array}$ & $\begin{array}{l}-0.89^{* *} \\
(-2.49)\end{array}$ & $\begin{array}{l}-1.61^{\star * *} \\
(-2.70)\end{array}$ & $\begin{array}{l}-0.52 \\
(-0.87)\end{array}$ & $\begin{array}{l}-1.49^{*} \\
(-1.71)\end{array}$ & $\begin{array}{l}-0.17 \\
(-0.31)\end{array}$ & $\begin{array}{l}-1.41^{*} \\
(-1.71)\end{array}$ \\
\hline F-stat of instrument & - & 259.61 & - & 57.86 & - & 222.82 & - & 55.42 \\
\hline $\begin{array}{l}\text { 4. Region-education-age } \\
\text { groups }\end{array}$ & $\begin{array}{l}-1.20^{\star * *} \\
(-3.19)\end{array}$ & $\begin{array}{l}-2.43^{* * *} \\
(-3.79)\end{array}$ & $\begin{array}{l}-0.74^{* *} \\
(-2.17)\end{array}$ & $\begin{array}{l}-2.49^{\star \star \star} \\
(-2.70)\end{array}$ & $\begin{array}{l}-0.15 \\
(-0.29)\end{array}$ & $\begin{array}{l}-1.98^{\star *} \\
(-2.30)\end{array}$ & $\begin{array}{l}0.09 \\
(0.19)\end{array}$ & $\begin{array}{l}-2.12^{* *} \\
(-2.30)\end{array}$ \\
\hline F-stat of instrument & - & 165.56 & - & 93.65 & - & 113.22 & - & 62.27 \\
\hline
\end{tabular}

Key. ${ }^{* * *},{ }^{* *},{ }^{*}$ denote statistical significance from zero at the 1\%,5\%,10\% significance level. T-statistics are indicated in parentheses below the point estimate.

Notes. The table reports the estimated effects of the 1962 repatriates on the wages of pre-existing male native workers with similar skills. I use a shift-share instrument. Specification 1 has 168 observations (4 education groups, 2 occupations and 21 regions). Specification 2 has 252 observations (6 education groups, 2 occupations and 21 regions). Specification 3 has 84 observations (4 education groups and 21 regions). Specification 4 has 252 observations (4 education groups, 3 age groups and 21 regions). Each regression includes skill fixed effects and is weighted by using the number of individuals used to compute the dependent variable. 
Table 8: The impact of repatriates on native employment opportunities (1962-1968)

\begin{tabular}{|c|c|c|c|c|c|c|c|c|}
\hline & \multicolumn{4}{|c|}{$\triangle$ Employment rate to Population } & \multicolumn{4}{|c|}{$\triangle$ Participation rate } \\
\hline & \multicolumn{2}{|c|}{ Men } & \multicolumn{2}{|c|}{ Women } & \multicolumn{2}{|c|}{ Men } & \multicolumn{2}{|c|}{ Women } \\
\hline & OLS & IV & OLS & IV & OLS & IV & OLS & IV \\
\hline \multirow[t]{2}{*}{ 1. Baseline } & $-0.33^{* *}$ & $-0.35^{\star *}$ & $-1.13^{\star *}$ & $-1.16^{\star *}$ & $-0.14^{* *}$ & $-0.15^{\star *}$ & $-1.13^{\star *}$ & $-1.10^{* *}$ \\
\hline & $(-2.28)$ & $(-2.20)$ & $(-2.28)$ & $(-2.38)$ & $(-2.11)$ & $(-2.25)$ & $(-2.31)$ & $(-2.34)$ \\
\hline \multirow[t]{3}{*}{ 2. Alternative $\Delta m_{r}^{1962}$} & $-0.29^{* *}$ & $-0.31^{* *}$ & $-0.82^{*}$ & $-0.98^{* *}$ & $-0.12^{*}$ & $-0.14^{\star *}$ & $-0.84^{*}$ & $-0.92^{* *}$ \\
\hline & $(-2.11)$ & $(-2.20)$ & $(-1.86)$ & $(-2.33)$ & $(-1.95)$ & $(-2.24)$ & $(-1.94)$ & $(-2.29)$ \\
\hline & \multicolumn{8}{|c|}{ Subsample regressions } \\
\hline \multirow[t]{2}{*}{ 3. High education } & 0.06 & 0.03 & -0.31 & -0.47 & $0.12^{*}$ & 0.06 & -0.11 & -0.29 \\
\hline & $(1.10)$ & $(0.59)$ & $(-0.51)$ & $(-0.73)$ & $(1.84)$ & $(0.87)$ & $(-0.19)$ & $(-0.46)$ \\
\hline \multirow[t]{2}{*}{ 4. Non-high education } & $-0.39^{* *}$ & $-0.40^{* *}$ & $-1.24^{\star *}$ & $-1.25^{\star *}$ & $-0.18^{\star *}$ & $-0.18^{* *}$ & $-1.29^{* *}$ & $-1.21^{* *}$ \\
\hline & $(-2.31)$ & $(-2.17)$ & $(-2.10)$ & $(-2.18)$ & $(-2.28)$ & $(-2.27)$ & $(-2.22)$ & $(-2.20)$ \\
\hline
\end{tabular}

Key. ${ }^{* * *},{ }^{* *},{ }^{*}$ denote statistical significance from zero at the $1 \%, 5 \%, 10 \%$ significance level. T-statistics are indicated in parentheses below the point estimate.

Notes. The left-part of the table reports the estimated effects of the 1962 repatriates on the employment rate to population of preexisting native workers. The right-part of the table reports the estimated effects of the 1962 repatriates on the participation rate of pre-existing native workers. I use rainfall intensity across regions as instrument. Specifications 1 and 2 have 84 observations (4 education groups and 21 regions) and include education fixed effects. Specifications 3 and 4 include education fixed effects. They respectively have 21 and 63 observations. Each regression is weighted by using the number of individuals used to compute the dependent variable in 1962 and 1968. Standard errors are adjusted for clustering at the regional level. 


\section{Appendix}

Table 9: Employment status of natives and repatriates by gender

\begin{tabular}{|c|c|c|c|c|c|c|}
\hline & \multicolumn{3}{|c|}{ Sample of men } & \multicolumn{3}{|c|}{ Sample of women } \\
\hline & \multicolumn{2}{|c|}{ Pre-existing natives } & \multirow{2}{*}{$\begin{array}{c}\text { Repatriates } \\
1968\end{array}$} & \multicolumn{2}{|c|}{ Pre-existing natives } & \multirow{2}{*}{$\begin{array}{c}\text { Repatriates } \\
1968\end{array}$} \\
\hline & 1962 & 1968 & & 1962 & 1968 & \\
\hline \multicolumn{7}{|c|}{ Employment Status } \\
\hline Employed & 89.6 & 88.2 & 88.6 & 37.0 & 41.2 & 32.7 \\
\hline Unemployed & 1.0 & 1.9 & 3.4 & 0.8 & 1.5 & 2.7 \\
\hline Inactive & 9.4 & 9.9 & 8.0 & 62.2 & 57.3 & 64.6 \\
\hline
\end{tabular}

Notes. The population used includes men and women aged from 18 to 64 , not enrolled at school and not self-employed. Corsica is not included in the sample. 
Table 10: The relative density of male repatriates across education groups and regions

\begin{tabular}{|c|c|c|c|c|c|}
\hline \multirow[b]{2}{*}{ Rank } & \multirow[b]{2}{*}{ French region } & \multicolumn{4}{|c|}{ Relative density of repatriates: $\pi_{i}=\frac{M_{i} / M}{N_{i}^{1} / N^{1}}$} \\
\hline & & $\begin{array}{c}\text { High } \\
\text { education }\end{array}$ & $\begin{array}{l}\text { Medium } \\
\text { education }\end{array}$ & $\begin{array}{l}\text { Low } \\
\text { education }\end{array}$ & $\begin{array}{l}\text { Very low } \\
\text { education }\end{array}$ \\
\hline 1 & Prov. Côte d'Azur & 0.9 & 0.9 & 1.0 & 1.1 \\
\hline 2 & Languedoc-Roussillon & 1.0 & 1.1 & 0.9 & 1.0 \\
\hline 3 & Midi-Pyrénées & 1.1 & 1.1 & 1.0 & 0.8 \\
\hline 4 & Rhône-Alpes & 0.8 & 0.9 & 1.0 & 1.2 \\
\hline 5 & Aquitaine & 1.5 & 1.1 & 1.1 & 0.6 \\
\hline 6 & Île-de-France & 1.2 & 0.9 & 0.8 & 1.2 \\
\hline 7 & Centre & 1.7 & 1.1 & 1.0 & 0.8 \\
\hline 8 & Bourgogne & 1.5 & 1.1 & 1.1 & 0.7 \\
\hline 9 & Franche-Comté & 1.1 & 0.9 & 0.9 & 1.1 \\
\hline 10 & Champagne-Ardenne & 1.9 & 1.1 & 0.8 & 0.8 \\
\hline 11 & Poitou-Charentes & 2.1 & 1.4 & 1.0 & 0.5 \\
\hline 12 & Lorraine & 1.5 & 0.7 & 0.8 & 1.2 \\
\hline 13 & Auvergne & 1.5 & 1.1 & 0.9 & 0.8 \\
\hline 14 & Alsace & 1.3 & 0.8 & 1.1 & 1.0 \\
\hline 15 & Haute-Normandie & 1.8 & 1.0 & 1.2 & 0.7 \\
\hline 16 & Picardie & 2.1 & 1.1 & 0.8 & 0.8 \\
\hline 17 & Limousin & 2.1 & 1.0 & 1.1 & 0.5 \\
\hline 18 & Pays de la Loire & 2.2 & 1.1 & 1.1 & 0.5 \\
\hline 19 & Basse-Normandie & 2.4 & 1.2 & 1.2 & 0.5 \\
\hline 20 & Bretagne & 2.1 & 1.0 & 1.0 & 0.6 \\
\hline 21 & Nord-Pas-de-Calais & 1.4 & 0.8 & 0.8 & 1.2 \\
\hline
\end{tabular}

Notes. The population used includes men in the labor force aged from 18 to 64, not enrolled at school and not self-employed. Corsica is not included in the sample. 
Table 11: The impact of repatriates on native internal migration between 1962 and 1968

\begin{tabular}{|c|c|c|c|c|c|c|}
\hline & \multicolumn{3}{|c|}{ Method from Peri \& al. (2011) } & \multicolumn{3}{|c|}{ Method from Borjas (2006) } \\
\hline & \multicolumn{2}{|r|}{ Men } & \multirow[b]{2}{*}{ Women } & \multicolumn{2}{|r|}{ Men } & \multirow[b]{2}{*}{ Women } \\
\hline & All & High education & & All & High education & \\
\hline 1. OLS estimate & $\begin{array}{c}0.20 \\
(1.68)\end{array}$ & $\begin{array}{c}0.20 \\
(1.15)\end{array}$ & $\begin{array}{c}0.17^{*} \\
(1.89)\end{array}$ & $\begin{array}{c}0.09 \\
(0.33)\end{array}$ & $\begin{array}{c}0.08 \\
(0.12)\end{array}$ & $\begin{array}{l}-0.08 \\
(-0.38)\end{array}$ \\
\hline $\begin{array}{l}\text { 2. IV estimate using } \\
\text { rainfall as instrument }\end{array}$ & $\begin{array}{c}0.08 \\
(0.91)\end{array}$ & $\begin{array}{c}0.14 \\
(0.92)\end{array}$ & $\begin{array}{l}-0.04 \\
(-0.32)\end{array}$ & $\begin{array}{c}0.19 \\
(0.72)\end{array}$ & $\begin{array}{c}0.43 \\
(0.57)\end{array}$ & $\begin{array}{l}-0.07 \\
(-0.35)\end{array}$ \\
\hline F-stat of instrument & 105.66 & 161.61 & 73.64 & 83.11 & 101.88 & 119.30 \\
\hline $\begin{array}{l}\text { 3. IV estimate using } \\
\text { distance as instrument }\end{array}$ & $\begin{array}{c}0.31 \\
(1.39)\end{array}$ & $\begin{array}{c}0.25 \\
(1.36)\end{array}$ & $\begin{array}{c}0.16 \\
(0.69)\end{array}$ & $\begin{array}{c}0.52 \\
(1.14)\end{array}$ & $\begin{array}{c}1.90 \\
(1.21)\end{array}$ & $\begin{array}{c}0.10 \\
(0.30)\end{array}$ \\
\hline F-stat of instrument & 16.72 & 23.05 & 15.66 & 13.98 & 12.88 & 16.91 \\
\hline $\begin{array}{l}\text { 4. IV estimate using } \\
\text { shift-share instrument }\end{array}$ & $\begin{array}{l}-0.13 \\
(-0.67)\end{array}$ & $\begin{array}{c}0.06 \\
(0.51)\end{array}$ & $\begin{array}{l}-0.12 \\
(-0.80)\end{array}$ & $\begin{array}{l}-0.11 \\
(-0.40)\end{array}$ & $\begin{array}{l}-0.87 \\
(-0.90)\end{array}$ & $\begin{array}{l}-0.21 \\
(-1.01)\end{array}$ \\
\hline F-stat of instrument & 192.41 & 94.59 & 346.12 & 375.15 & 340.16 & 742.09 \\
\hline Cluster & 21 & 21 & 21 & 21 & 21 & 21 \\
\hline Observations & 84 & 84 & 84 & 84 & 84 & 84 \\
\hline
\end{tabular}

Key. ${ }^{* *},{ }^{* *},{ }^{*}$ denote statistical significance from zero at the $1 \%, 5 \%, 10 \%$ significance level. T-statistics are indicated in parentheses below the point estimate.

Notes. The table reports the estimated effects of the 1962 repatriates on the internal migration of pre-existing native workers between 1962 and 1968 using two empirical methodologies from Borjas $(2006,2014)$ and Peri and Sparber (2011a). Each Specification has 84 observations and include education fixed effects. Each regression is weighted by using the number of individuals used to compute the dependent variable in 1962 and 1968. Standard errors are adjusted for clustering at the regional level. 
Table 12: The impact of repatriates on native wages by using wild-bootstrap methods

\begin{tabular}{|c|c|c|c|c|}
\hline & \multicolumn{4}{|c|}{ Change in native wages between } \\
\hline & \multicolumn{2}{|c|}{$1962-1968$} & \multicolumn{2}{|c|}{$1962-1976$} \\
\hline & Baseline & $\begin{array}{l}\text { Additional } \\
\text { controls }\end{array}$ & Baseline & $\begin{array}{l}\text { Additional } \\
\text { controls }\end{array}$ \\
\hline IV estimates & -1.91 & -2.07 & -0.97 & -0.72 \\
\hline $95 \% \mathrm{Cl}$ using robust standard errors & {$[-2.92 ;-0.90]$} & {$[-3.20 ;-0.93]$} & {$[-2.01 ; 0.06]$} & {$[-2.19 ; 0.75]$} \\
\hline $95 \% \mathrm{Cl}$ using clustering at the regional level & {$[-3.37 ;-0.45]$} & {$[-3.68 ;-0.46]$} & {$[-2.29 ; 0.35]$} & {$[-3.01 ; 1.65]$} \\
\hline $\begin{array}{l}95 \% \mathrm{Cl} \text { using the wild-bootstrap method } \\
\text { from Davidson and MacKinnon (2010) }\end{array}$ & {$[-5.89 ;-0.16]$} & {$[-5.76 ;-0.31]$} & {$[-3.31 ; 0.16]$} & {$[-5.06 ; 1.96]$} \\
\hline Education-sector FE & Yes & Yes & Yes & Yes \\
\hline Observations & 168 & 168 & 168 & 168 \\
\hline
\end{tabular}

Key. ${ }^{* * *},{ }^{* *},{ }^{*}$ denote statistical significance from zero at the $1 \%, 5 \%, 10 \%$ significance level. T-statistics are indicated in parentheses below the point estimate.

Notes. The table reports the IV estimated coefficients from the baseline regressions used in Table 3. I provide the 95\% confidence intervals of the IV estimates computed by (i) using heteroscedastic-consistent estimates of the standard errors, (ii) clustering standard errors at the regional level and (iii) using the wild-bootstrap method (10,000 replications) as proposed by Davidson and MacKinnon (2010) . I use rainfall intensity across regions as instrument. All regressions have 168 observations (4 education groups, 2 occupations and 21 regions) and include skill fixed effects. Each regression is weighted by using the number of individuals used to compute the dependent variable. 
Table 13: Additional descriptive statistics of French Regions

\begin{tabular}{|c|c|c|c|c|c|c|c|}
\hline \multirow[b]{3}{*}{ Rank } & \multirow[b]{3}{*}{ French region } & & & \multicolumn{4}{|c|}{ Time period: 1962-1968 } \\
\hline & & \multicolumn{2}{|c|}{$\triangle$ Male wages } & \multicolumn{2}{|c|}{$\begin{array}{l}\triangle \text { Employment } \\
\text { rate to population }\end{array}$} & \multicolumn{2}{|c|}{$\begin{array}{l}\triangle \text { Participation } \\
\text { rate }\end{array}$} \\
\hline & & $1962-1968$ & 1968-1976 & Men & Women & Men & Women \\
\hline 1 & Prov. Côte d'Azur & 26.5 & 31.0 & 6.2 & 17.4 & -0.9 & 16.5 \\
\hline 2 & Languedoc-Roussillon & 18.7 & 38.4 & 7.6 & 18.8 & -0.3 & 23.5 \\
\hline 3 & Midi-Pyrénées & 30.0 & 32.7 & 8.7 & 18.2 & -1.5 & 12.6 \\
\hline 4 & Rhône-Alpes & 29.1 & 31.0 & 11.8 & 12.6 & -0.1 & 8.7 \\
\hline 5 & Aquitaine & 39.4 & 42.1 & 6.3 & 15.3 & -1.5 & 16.1 \\
\hline 6 & Île-de-France & 21.0 & 27.0 & 2.4 & 3.9 & -0.5 & 7.1 \\
\hline 7 & Centre & 32.7 & 41.4 & 8.9 & 19.1 & -0.1 & 15.9 \\
\hline 8 & Bourgogne & 33.8 & 25.3 & 6.8 & 20.2 & 0.1 & 19.8 \\
\hline 9 & Franche-Comté & 31.4 & 22.4 & 11.7 & 18.7 & 0.4 & 13.7 \\
\hline 10 & Champagne-Ardenne & 36.8 & 30.9 & 11.4 & 20.5 & -0.3 & 15.4 \\
\hline 11 & Poitou-Charentes & 27.2 & 44.3 & 5.8 & 19.1 & -1.4 & 19.8 \\
\hline 12 & Lorraine & 36.2 & 21.7 & 4.3 & 14.6 & -1.6 & 18.3 \\
\hline 13 & Auvergne & 17.9 & 41.9 & 8.8 & 17.5 & -0.2 & 20.4 \\
\hline 14 & Alsace & 30.9 & 24.1 & 8.7 & 10.8 & -1.8 & 12.8 \\
\hline 15 & Haute-Normandie & 35.5 & 33.8 & 11.7 & 19.2 & 0.0 & 13.6 \\
\hline 16 & Picardie & 28.2 & 32.3 & 10.9 & 26.3 & -0.5 & 20.0 \\
\hline 17 & Limousin & 32.8 & 28.6 & 5.6 & 17.1 & -1.1 & 17.9 \\
\hline 18 & Pays de la Loire & 36.0 & 35.4 & 11.8 & 22.6 & -0.8 & 17.3 \\
\hline 19 & Basse-Normandie & 27.1 & 31.4 & 11.2 & 20.2 & 0.8 & 17.8 \\
\hline 20 & Bretagne & 33.6 & 28.2 & 10.3 & 22.7 & 0.2 & 21.1 \\
\hline 21 & Nord-Pas-de-Calais & 27.1 & 34.4 & 3.5 & 15.7 & -0.9 & 17.2 \\
\hline
\end{tabular}

Notes. The population used includes men and women in the labor force aged from 18 to 64 , not enrolled at school and not selfemployed. Corsica is not included in the sample. I compute the changes in male wages, employment and participation rate for pre-existing natives. 


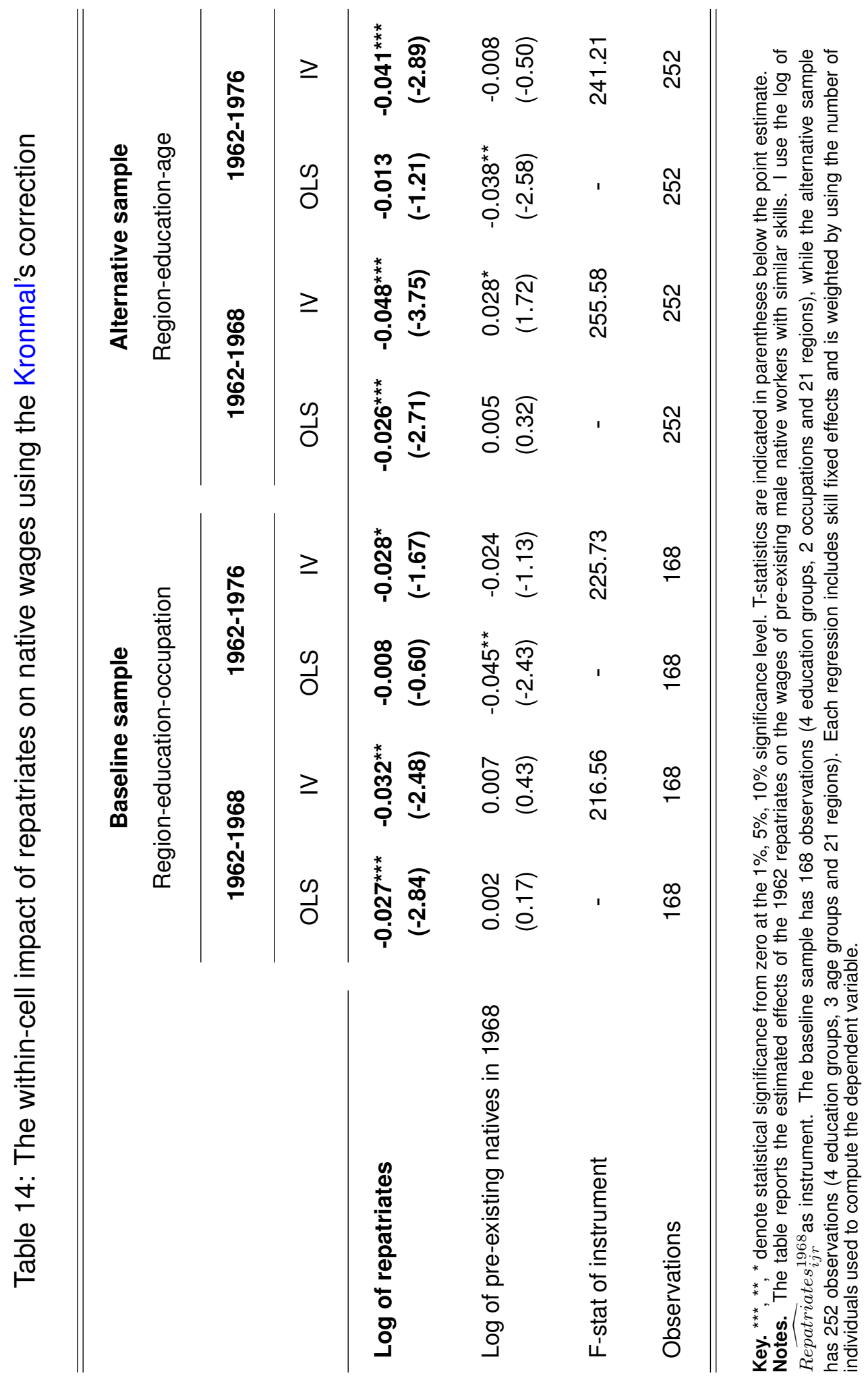

